\title{
Ubiquitin-proteasome system (UPS) as a target for anticancer treatment
}

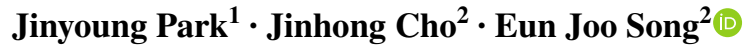

Received: 27 September 2020 / Accepted: 24 October 2020 / Published online: 9 November 2020

(C) The Pharmaceutical Society of Korea 2020

\begin{abstract}
The ubiquitin-proteasome system (UPS) plays an important role in the cellular processes for protein quality control and homeostasis. Dysregulation of the UPS has been implicated in numerous diseases, including cancer. Indeed, components of UPS are frequently mutated or abnormally expressed in various cancers. Since Bortezomib, a proteasome inhibitor, received FDA approval for the treatment of multiple myeloma and mantle cell lymphoma, increasing numbers of researchers have been seeking drugs targeting the UPS as a cancer therapeutic strategy. Here, we introduce the essential component of UPS, including ubiquitinating enzymes, deubiquitinating enzymes and 26S proteasome, and we summarize their targets and mechanisms that are crucial for tumorigenesis. In addition, we briefly discuss some UPS inhibitors, which are currently in clinical trials as cancer therapeutics.
\end{abstract}

Keywords Ubiquitin-proteasome system (UPS) · E3 ligase $\cdot$ Deubiquitinating enzymes (DUBs) $\cdot$ Proteasome $\cdot$ Cancer $\cdot$ Small molecule inhibitors

\section{Introduction}

The ubiquitin-proteasome system (UPS) is the major proteolytic system that controls protein degradation and it regulates

Eun Joo Song

esong@ewha.ac.kr

1 Molecular Recognition Research Center, Korea Institute of Science and Technology, Hwarangno 14-gil 5, Seongbuk-gu, Seoul 02792, Korea

2 Graduate School of Pharmaceutical Sciences, College of Pharmacy, Ewha Womans University, 52, Ewhayeodae-gil, Seodaemun-gu, Seoul 03760, Korea many cellular processes in eukaryotic cells, such as DNA repair, stress responses and cell proliferation. The UPS consists of specific enzymes that modify protein substrates using ubiquitin, and 26S proteasomes responsible for proteolysis of ubiquitin-tagging substrates (Mata-Cantero et al. 2015). This ubiquitin conjugation to the substrate is carried out by a multistep cascade reaction consisting of the E1, E2, and E3 enzymes. In brief, ubiquitin-activating enzymes (E1s) use energy from ATP hydrolysis to generate thioester bond between the $\mathrm{C}$-terminal of ubiquitin and a Cys residue in the active catalytic site of E1 enzymes. This activated ubiquitin is then transferred to the ubiquitin-conjugating enzymes (E2s), which forms a thioester bond between E2 enzymes and the ubiquitin. Finally, the charged E2 enzymes cooperate with one of hundreds of ubiquitin ligases (E3s) to transfer the activated ubiquitin to a target substrate (Fig. 1) (Eldridge and O'Brien 2010; Yuan et al. 2018).

\section{E1, E2, E3 ubiquitinating enzymes}

The human genome contains two E1 genes, UBA1 and UBA6, about fifty E2 genes and genes encoding around seven hundred E3 enzymes. These E3 enzymes are generally classified into three groups based on the mechanism that they use to transfer ubiquitin from the E2 enzyme to the substrate: the 'really interesting new gene' (RING) class, the 'homologous to E6-AP carboxyl terminus' (HECT) class, and the 'RING-between-RING' (RBR) class (Gupta et al. 2018; Zhang et al. 2020). The RING class, the largest class of E3 enzymes, helps transfer the ubiquitin attached to E2 directly to the substrate without forming thioester bonds with ubiquitin (Lorick et al. 1999; Mani and Gelmann 2005). The HECT class forms a catalytic Cys-dependent intermediate with ubiquitin attached to E2, and then transfers it to a target substrate (Huibregtse 


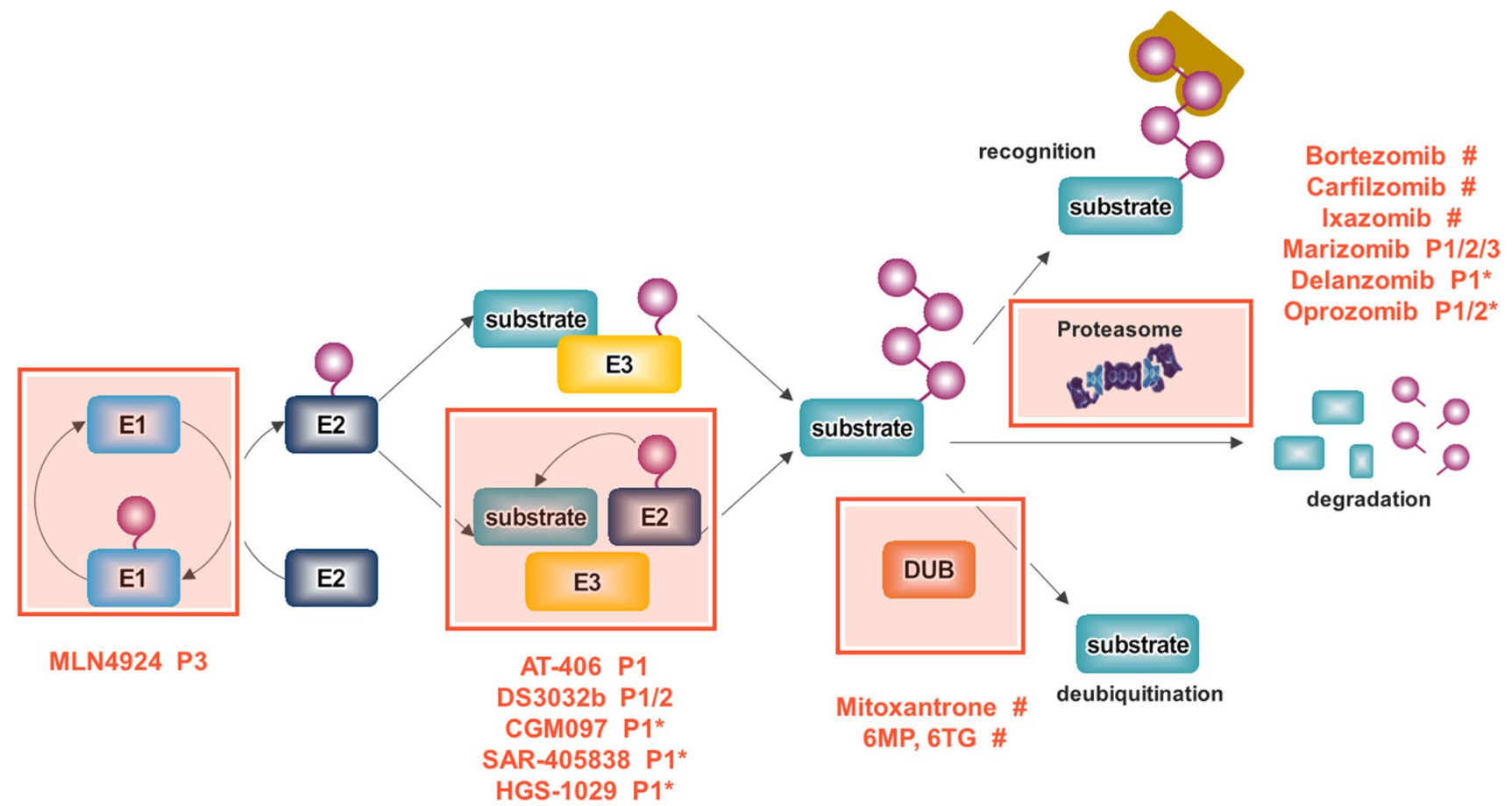

Fig. 1 The overview of UPS and inhibitors in clinical trials to target UPS. UPS is representative process for protein degradation consisting of ubiquitinating enzyms (E1, 32, and E3), 26S proteasome, and deubiquitinating enzymes. A number of small molecule inhibitors targeting the components of UPS are developed for cancer therapeutics. $P$ phase, *phase completed, \#FDA approved but under phase I-IV for another indication

et al. 1995; Scheffner et al. 1995). The RBR class has two canonical RING domains (RING1 and RING2) linking an 'in-between RING' (IBR) domain (Wenzel et al. 2011). The RING1 domain initially recognizes the ubiquitinattached E2 (RING-like), but then the RING2 domain offers a Cys residue to the active site of E2 (HECT-like) which forms a thioester intermediate with the ubiquitin attached to the E2 (Gupta et al. 2018).

Ubiquitin contains seven Lys residues including Lys6, $11,27,29,33,48$, and 63, and all of them can covalently attach to other ubiquitins; thus, various linear or branched ubiquitin chains are formed (Pohl and Dikic 2019). Among these polyubiquitin chains, Lys48 and Lys11-linked polyubiquitin chains serve as the most potent signals for degradation by the proteasome, whereas Lys63-linked chains are more typically associated with non-proteasomal signaling, including endocytic trafficking, DNA replication and signal transduction. However, Mckeon et al. reported that Lys63-ubiquitination could also induce substrate degradation via the autophagy-lysosome pathway (McKeon et al. 2015). Other linkage types are less well-characterized, even though some reports have shown that Lys6, 27, 29, and 33-linked polyubiquitin chains are involved in proteasomal degradation (Xu et al. 2009). Recently, systemic analysis has revealed that monoubiquitination can also target some small proteins, particularly proteins of 20 to 150 residues, for degradation by the proteasome (Shabek et al. 2007, 2009, 2012; Nakagawa and Nakayama 2015; Braten et al. 2016).

\section{Deubiquitinating enzymes (DUBs)}

Ubiquitination is a dynamic and highly reversible process. Deubiquitinating enzymes (DUBs) can counteract the activity of E3 ligases by removing the ubiquitin chain from the target proteins, which prevents their degradation and reverses other functional changes caused by the ubiquitination. In addition, DUBs have crucial roles in maintaining ubiquitin homeostasis via their involvement in ubiquitin maturation, editing and recycling (Komander et al. 2009). The human genome encodes more than one hundred DUBs, and they are classified into eight families: ubiquitin-specific proteases (USPs), ovarian tumor proteases (OTUs), ubiquitin C-terminal hydrolases (UCHs), Machado-Joseph disease protein domain proteases (MJDs), JAP1/MPN/Mov34 metallopeptidases (JAMMs), the motif interacting with ubiquitin-containing novel DUB family (MINDY), the monocyte chemotactic protein-induced protein (MCPIP), and zinc-finger and UFM1-specific peptidases (ZUFSPs) (Reyes-Turcu et al. 2009; Liang et al. 2010; Abdul Rehman et al. 2016; Hermanns et al. 2018). In addition to reversing ubiquitination, DUBs control multiple cellular pathways such as protein trafficking, chromatin remodeling, cell cycle regulation 
and apoptosis. Therefore, DUBs play roles in a variety of clinical diseases.

\section{$26 \mathrm{~S}$ proteasome}

The $26 \mathrm{~S}$ proteasome, composed of one $20 \mathrm{~S}$ core particle (20S CP) and one or two 19S regulatory particles (19S RP), is an ATP-dependent multi-subunit complex responsible for hydrolyzing the protein into small peptides. The 20S CP is a barrel-shaped proteolytic core that contains active catalytic sites and is where proteolysis finally occurs, while the $19 \mathrm{~S}$ RPs serves to selectively and effectively transfer ubiquitinated proteins to the 20S CP by mediating deubiquitination (Groll et al. 1997; Glickman et al. 1998; Bedford et al. 2010; Selvaraju et al. 2015). The 20S CP consists of four stacked heptameric rings $(7 \alpha, 7 \beta, 7 \beta$ and $7 \alpha)$ around a central cavity. The outer two $\alpha$ rings allow the interaction with the $19 \mathrm{~S}$ RPs, while the inner two $\beta$ rings consist of a total of seven $\beta$ subunits, of which three $\beta$ subunits $(\beta 1, \beta 2$ and $\beta 5)$ are responsible for proteolytic activity (Arendt and Hochstrasser 1999; Voges et al. 1999; Nguyen et al. 2013). The 19S RP has at least 19 subunits and is composed of a lid and a base. Ubiquitinated proteins are captured by specific receptors on the 19S RP, and then they are deubiquitinated by proteasome-associated DUBs (Arendt and Hochstrasser 1999; Voges et al. 1999; Lee et al. 2011). Six different ATPase subunits in the base of the 19S RP supply energy to open the lid of the proteasome channel (Ciechanover 2005).

\section{E3 ubiquitin ligases in cancer}

Several E3 ligases have been reported to be mutated or overexpressed in various cancers. The resulting dysfunction of E3 ligases affects DNA damage repair, cell cycle regulation, gene expression, and signaling transduction. Here, we introduce some ubiquitinating enzymes involved in oncogenic signaling and cancer progression (Fig. 2a).

\section{Anaphase-promoting complex (APC/C)}

$\mathrm{APC} / \mathrm{C}$ is a representative $\mathrm{E} 3$ ligase essential for mitosis progression. Although APC/C itself is rarely mutated in cancer, it has been reported that deregulation of its co-activators cell division cycle 20 (CDC20) or CDC20-like protein 1 (CDH1) is associated with cancers (Senft et al. 2018).

$\mathrm{CDH} 1$-deficient old mice exhibit increased rates of spontaneous epithelial tumors in various organs and downregulation of CDH1 induces premature S-phase entry and genomic instability, indicating that $\mathrm{CDH} 1$ acts as a tumor suppressor (Garcia-Higuera et al. 2008; Greil et al. 2016). CDH1 promotes ubiquitination-mediated proteolysis of BRAF, the downstream effector of RAS that drives tumorigenesis, in both APC-dependent and -independent manners. However, hyperactivated ERK and CDK4 phosphorylate $\mathrm{CDH} 1$ and disrupt the formation of the APC-CDH1 complex, leading to BRAF dimerization and activation in various cancer cells (Wan et al. 2017). Furthermore, CDH1 is involved in the proliferation of breast cancer cells by inhibiting the kinase activity of c-Src, a proto-oncogene, in an APC-independent manner. Conversely, c-Src suppresses $\mathrm{CDH} 1$ activity by phosphorylating it (Han et al. 2019). Besides, CDH1 restrains oncogenic signals such as polo like kinase (PLK), mitotic cyclins, and Skp2 (Fujita et al. 2009; Zhang et al. 2014). In contrast to CDH1, CDC20 is often overexpressed in a variety of cancers. Moreover, inhibition of CDC20 blocks mitotic exit and induces apoptosis, suggesting that CDC20 has oncogenic properties (Huang et al. 2009; Manchado et al. 2010). The depletion of CDC20 inhibits Wnt signaling and subsequently attenuates cell proliferation in colorectal cancer cells (Kidokoro et al. 2008; Hadjihannas et al. 2012).

\section{S-phase kinase-associated protein 1 (SKP1)-cullin1-F-box protein (SCF) complex}

The SCF E3 ligase complex, a multimeric ubiquitination complex consisting of cullin1, SKP1 and one of about 70 F-box proteins, plays multiple roles in cellular processes. The main scaffold of the SCF complex, cullin1 directly binds to SKP1, which then binds an F-box protein that directly binds to their substrates.

F-box and WD repeat domain-containing 7 (FBXW7) is a key component of the SCF E3 ligase complex that regulates the stability of cell cycle regulators (e.g., cyclin $\mathrm{E}$ and Aurora A), oncogenic transcription factors (e.g., c-Myc), cell surface receptors (e.g., Notch1), and signaling molecules (e.g., mTOR) (Fujii et al. 2006; Yang et al. 2015). Therefore, impaired SCF-FBXW7 function leads to sustained proliferation and survival, genomic instability, and signaling programs that affect cancer invasion and metastasis (Mao et al. 2004; Rajagopalan et al. 2004; Grim et al. 2012). For example, decreased FBXW7 promotes mTOR activity that support the metastatic potential of cholangiocarcinoma (CCA) to the liver and lung (Yang et al. 2015). In addition, the deletion of FBXW7 increases cyclin E expression and Aurora A deregulation, resulting in chromosomal instability in mice (Koepp et al. 2001; Moberg et al. 2001; Strohmaier et al. 2001; Mao et al. 2004). Indeed, FBXW7 is downregulated in breast, colorectal, and gastric cancers. Its loss is correlated with a poor prognosis and survival, and increased invasion and metastasis (Iwatsuki et al. 2010; Ibusuki et al. 2011; Yang et al. 2015).

SKP2 is an F-box protein of the SCF E3 ligase complex and it is responsible for the degradation of several cyclindependent kinase (CDK) inhibitors, such as p21 ${ }^{\text {Cip1 }}, \mathrm{p} 27^{\text {Kip1 }}$, 
(A)

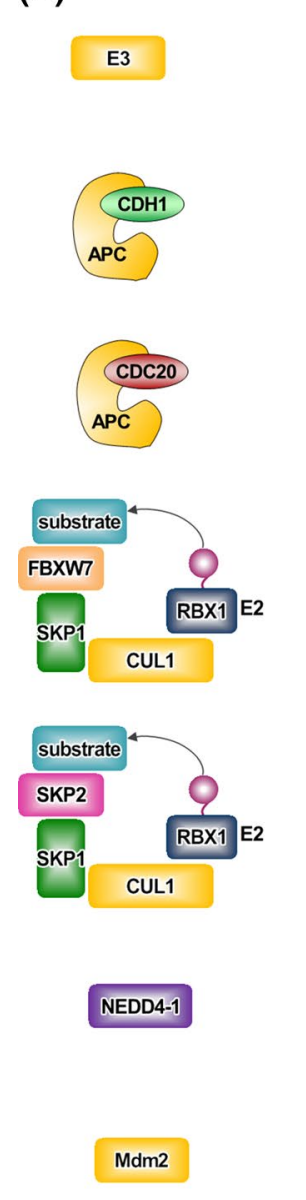

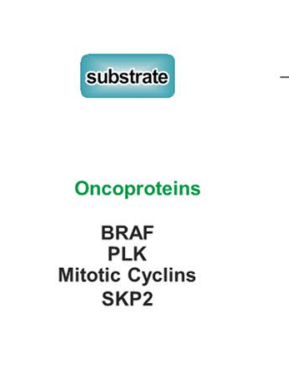

Mitotic exit related proteins

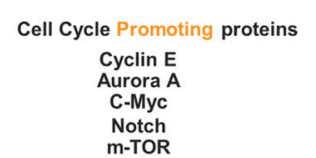

Cell Cycle Regulating proteins
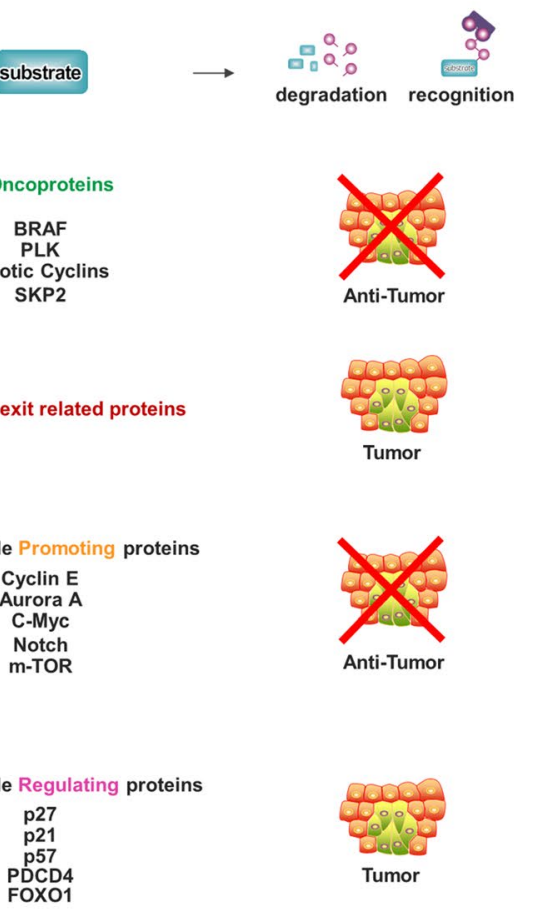

(B)

DUB
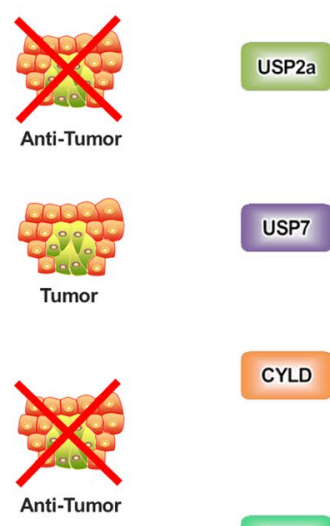

CYLD
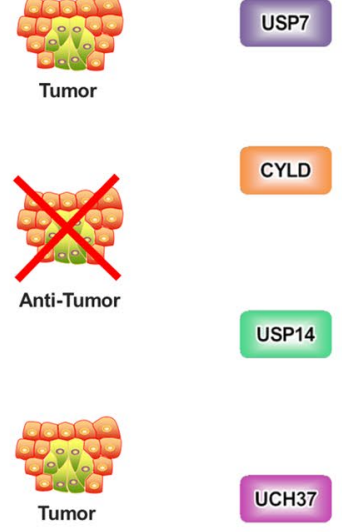

UCH37

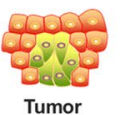

RPN11

\section{7}

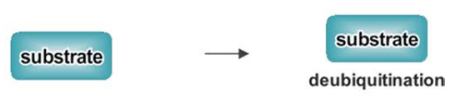

eubiquitination
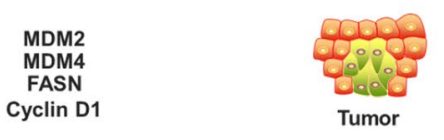

Cyclin D1

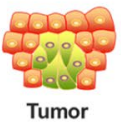

MDM2
PTEN
DNMT1
PHF8

Dvl

Bcl-3

TRAF-2

TRAF-6

NEMO

Androgen Receptor (AR)

Vimentin
Dvl

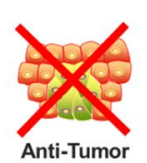

P14

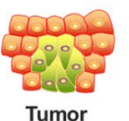

Type I TGF-b receptor

SMAD7
COPS5

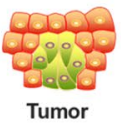

E2F1

ErbB2

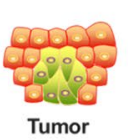

Fig. 2 Regulation of tumor progression by E3 ligases and DUBs. a Many E3 ligases and b DUBs are involved in cancer progression, and they have several substrates that participate in various biological signaling pathway. For example, USP7 stabilizes MDM2 and DNMT1, resulting in inhibiting cell apoptosis. Also, USP7 regulates PTEN localization and eventually inducing tumorigenesis. Some E3 ligases or DUBs can act as both oncogenic protein and tumor suppressor, depending on the target and type of cancer

and $\mathrm{p} 57^{\mathrm{Kip} 1}$. Among them, the best studied is the tumor suppressor $\mathrm{p} 27^{\mathrm{Kip} 1}$. SKP2 overexpression induces $\mathrm{p} 27^{\mathrm{Kip} 1} \mathrm{deg}$ radation, promoting cytokine-stimulated cell cycle progression and the survival of T-cell acute lymphoblastic leukemia (T-ALL) cells (Dohda et al. 2007). Indeed, several studies have shown that SKP2 expression is negatively correlated with p27 levels in different types of tumors (Hershko and Shapira 2006). It has been reported that oncogenic Notch upregulates SKP2 expression, consequently enhancing p2 $7^{\text {Kip1 }}$ degradation in T-ALL cells (Dohda et al. 2007). SKP2 inhibitor C1 (SKPin C1) prevents SKP2-mediated $\mathrm{p} 27^{\mathrm{Kip} 1}$ ubiquitination and degradation, leading to apoptosis by 27 accumulation and cell cycle arrest in uveal melanoma and multiple myeloma (MM) cell lines (Asmamaw et al. 2020). In addition, SKP2 promotes programmed cell death protein 4 (PDCD4) degradation by phosphorylation and ubiquitination, leading to increase cell proliferation and radiation tolerance in breast cancer ( $\mathrm{Li}$ et al. 2019). Also,
SKP2 ubiquitinates FOXO1, which is phosphorylated by AKT, and induces its proteasomal degradation, inhibiting apoptosis in prostate cancer cells (Huang et al. 2005).

\section{Neuronally expressed developmentally downregulated 4 -1 (NEDD4-1)}

NEDD4-1 has been demonstrated to play a critical role in regulating cancer progression. Overexpression of NEDD4-1 promotes tumorigenesis through ubiquitination and inactivation of phosphatase and tensin homolog (PTEN) in non-small cell lung carcinomas (NSCLC) and prostate cancer cells (Wang et al. 2007, 2008; Amodio et al. 2010). Also, NEDD4-1 stabilizes MDM2 by Lys63linked polyubiquitination, resulting in the promotion of p53 degradation and consequently cell proliferation $(\mathrm{Xu}$ et al. 2015). Moreover, NEDD4-1 binds to N-Myc and negatively regulates it by increasing its polyubiquitination, 
promoting cell proliferation in neuroblastoma cancer cells (Liu et al. 2013). Depletion of NEDD4-1 reduces the phosphorylation of AKT and increases PTEN levels, inhibiting cell growth and migration in hepatocellular carcinoma (HCC) cells (Huang et al. 2017). Meanwhile, NEDD4-1 suppresses tumorigenesis by inducing RAS degradation. RAS genes are frequently mutated in cancers and mutated RAS functions as an oncogene. Zeng et al. reported that RAS signaling stimulates the expression of NEDD4-1, which negatively regulates RAS levels. However, oncogenic-mutated RAS promotes the RAS-induced overexpression of NEDD4-1 and the degradation of PTEN by preventing NEDD4-1-mediated RAS ubiquitination, leading to tumorigenesis in RAS-driven tumors (Zeng et al. 2014). In addition, NEDD4-1 ubiquitinates phosphorylated AKT-Ser473 and induces its proteasomal degradation, inhibiting AKT signaling and promoting apoptosis of MM cells (Huang et al. 2020).

\section{MDM2}

MDM2 is an essential regulator of p53, which ubiquitinates p53 and induces its proteasomal degradation. Tumor suppressor p53 is an important transcription factor regulating cellular signaling that affects processes such as apoptosis, cell cycle, DNA repair and senescence. It is functionally impaired by mutation or deletion in about $50 \%$ of cancers. In contrast, MDM2 is overexpressed in many malignancies (Shangary and Wang 2008). Overexpressed MDM2 and mutated or downregulated p53 induces cisplatin resistance in several cancers (Kondo et al. 1995; Hayashi et al. 2006). Cisplatin is a drug that causes apoptosis in cancer cells by phosphorylating and activating p53. In addition, resistance to other chemotherapeutic drugs including temozolomide (Sato et al. 2011), doxorubicin (Suzuki et al. 1998) gemcitabine (Sheng et al. 2017), and fluorouracil (5-FU) (Han et al. 2018) is associated with MDM2-p53 negative feedback in many cancers.

\section{DUBs in cancer}

As mentioned above, the DUB do not just reverse ubiquitination, but they also have many diverse functions, such as protein trafficking, apoptosis, chromatin remodeling, DNA damage repair and cell cycle regulation, and are particularly involved in cell signaling related to cancers (Antao et al. 2020). Below, we describe some DUBs that act as tumor suppressors or oncogenic proteins in relation to cancers (Fig. 2b).

\section{USP2a}

USP2a regulates cell proliferation by deubiquitinating and stabilizing MDM2 and MDM4. Overexpression of USP2a causes an increase in MDM2 accumulation and promotes proteasomal degradation of $\mathrm{p} 53$, and thereby it has oncogenic properties in prostate cancer (Priolo et al. 2006; Stevenson et al. 2007). On the contrary, in glioma cells, overexpression of USP2a stabilizes MDM4 and facilitates the p53-dependent intrinsic apoptotic pathway in glioma cells (Wang et al. 2014a). It also deubiquitinates fatty acid synthase (FASN), resulting in increased FASN levels, thus enhancing cell proliferation in prostate cancer cells (Graner et al. 2004). Furthermore, USP2a directly interacts with cyclin D1 and promotes its stabilization. Cyclin D1 is a crucial regulator of the G1-S phase transition and it can function as a proto-oncoprotein that is overexpressed in various types of cancers. The accumulation of cyclin D1 by USP2a accelerates the $\mathrm{G} 1$ to $S$ phase progression and cell growth in cancer cells (Shan et al. 2009). Finally, the upregulation of USP2a has been reported to induce cell proliferation, migration, invasion and resistance to chemotherapeutic agents in bladder cancer (Kim et al. 2012), and it is associated with a poor prognosis in oral squamous cell carcinomas (da Silva et al. 2009).

\section{USP7}

USP7 is a well-known oncogenic protein. It has been reported that an excess amount of USP7 is directly correlated with the development of multiple cancers, such as prostate, colon, liver, lung, breast, glioma, and ovarian cancer (Tavana and Gu 2017; Bhattacharya et al. 2018). Typically, USP7 could stabilize MDM2 by deubiquitination and subsequently promotes the degradation of $\mathrm{p} 53$, causing the inhibition of apoptosis in cancer cells (Bhattacharya et al. 2018). In addition, USP7 has several other targets that are associated with tumor progression. For example, USP7 can deubiquitinate PTEN and regulate its localization. Nuclear PTEN is essential for tumor suppression, but when monoubiquitination of PTEN is reduced by USP7, PTEN migrates from the nucleus to the cytoplasm and eventually promotes tumorigenesis. Indeed, USP7 is overexpressed in prostate cancer, and high levels of USP7 are directly correlated with the nuclear exclusion of PTEN and tumor aggressiveness (Song et al. 2008). Also, USP7 deubiquitinates and stabilizes DNA methyltransferase 1 (DNMT1). Because fine-tuning of DNMT1 abundance through posttranslational modifications (PTMs) is important for tumor suppression, increased amounts of USP7 correlate with increased amounts of DNMT1 in colon cancer, consequently promoting tumor progression (Du et al. 2010). Moreover, USP7 promotes tumor progression by deubiquitinating and stabilizing the histone demethylase 
PHF8 and by upregulating cyclin A2 in breast cancer (Wang et al. 2016). USP7 also activates Wnt signaling in adenomatous polyposis coli gene (APC)-mutated colorectal cancer through $\beta$-catenin deubiquitination (Novellasdemunt et al. 2017). Conversely, the depletion of USP7 reduces the stability of the checkpoint with forkhead and ring-finger (CHRF), a mitotic E3 ligase, leading to the accumulation of Aurora A and cyclin B, and increased mitotic defects in a p53-independent manner. This mechanism may explain why breast cancer patients with low levels of USP7 are resistant to the Taxanes, a group of anticancer drugs including Taxol and Taxotere (Giovinazzi et al. 2013). Recently, He et al. reported that USP7 is associated with progression of MM. USP7 promotes MM cell survival by deubiquitinating Maf proteins, including c-Maf, MafA, and MafB, which are critical transcription factors in myelomagenesis. Indeed, USP7 is up-regulated in MM cell line and MM patients with high USP7 expression exhibit lower survival rate (He et al. 2020).

\section{Cylindromatosis (CYLD)}

CYLD was originally identified as a germline mutated gene in familial cylindromatosis (FC) (Bignell et al. 2000). CYLD mainly acts as a tumor suppressor in several cancers such as melanoma, human salivary gland (HSG) tumor, colon cancer, HCC, and breast cancer (Park et al. 2019). Wnt-mediated nuclear translocation of $\beta$-catenin enhances cylindroma cell proliferation. Downregulation of CYLD in cylindroma cells promotes $\beta$-catenin accumulation in the nucleus through Lys63-ubiquitination of Dishevelled (Dvl) (Tauriello et al. 2010). In addition, the expression of CYLD is reduced in melanoma. Repression of CYLD expression increases the ubiquitination of the proto-oncogene Bcl-3 and induces its translocation to the nucleus, resulting in increased expression of cyclin D1 and N-cadherin; thus, melanoma cell proliferation and invasion is enhanced (Massoumi et al. 2009).

CYLD is a critical negative regulator of NF- $\mathrm{KB}$ signaling (Park et al. 2019). Sustained NF-KB activity is associated with decreased CYLD expression in HSG tumors and HCC, leading to increased cell survival, tumor progression and metastasis (Fukuda et al. 2006, 2008; Hellerbrand et al. 2007). CYLD removes Lys63-polyubiquitin chains from TRAF-2, TRAF-6, and NEMO, which are intermediates of

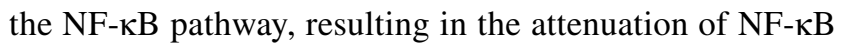
activity. However, in breast cancer cells, when CYLD is phosphorylated by overexpressed IкB kinases (IKK- $\alpha, \beta, \varepsilon$ ), it is dissociated from the NF- $\kappa B$ intermediates, increasing their ubiquitination, and eventually promoting cell proliferation. (Reiley et al. 2005; Hayden and Ghosh 2008; Hutti et al. 2009). Meanwhile, BRG1-and hBRM-associated factor (BAF57) induce cell cycle arrest and apoptosis by stimulating CYLD expression in breast cancer cells (Wang et al. 2005).

\section{A20}

Like CYLD, A20 suppresses cell proliferation and promotes apoptosis as a negative regulator of the NF- $\mathrm{KB}$ pathway, and it is well known to play an important role in inflammation and immunity (Dixit et al. 1990; Hoesel and Schmid 2013). Recently, many studies have proposed that A20 is highly involved in tumorigenesis. For example, A20 is frequently inactivated by somatic mutations or deletions in lymphomas, and its inactivation is associated with cancer progression (Tavares et al. 2010; Chu et al. 2011; Hovelmeyer et al. 2011). Meanwhile, A20 is highly expressed in diverse solid tumors; in these cases, the overexpression of A20 affects chemotherapy and radiation resistance (Guo et al. 2009; Chen et al. 2015; Yang et al. 2018).

A20 is unique in that it has both DUB and E3 ligase activities. Lee et al. reported that A20 facilitates TGF- $\beta 1$-induced epithelial-mesenchymal transition (EMT) and metastasis by increasing multi-monoubiquitination of Snaill in basal-like breast cancers (Lee et al. 2017).

\section{Proteasome-associated DUBs in cancer}

Three DUBs are associated with the 19S RP in mammalian cells. USP14 (also known as Ubp6) and UCH37 (also known as UCHL5) are cysteine proteases and are located in the lid. They mediate a stepwise removal of ubiquitin from the substrate by trimming the distal tip of the ubiquitin chain (Patel et al. 2018). The third DUB, RPN11 (also known as POH1) is a metalloprotease and it cleaves at the base of the ubiquitin chain where it is linked to the substrate (Lee et al. 2011). In particular, RPN11-mediated deubiquitination promotes substrates degradation, but USP14 and UCH37 antagonize degradation (Verma et al. 2002). Proteasome-associated DUBs play an important role in maintaining ubiquitin homeostasis through the removal of ubiquitin from the substrate and its recycling, and they regulate protein degradation by rescuing poorly ubiquitinated proteins or enhancing the activity of the proteasome (Lee et al. 2011).

\section{USP14}

USP14 is closely related to the progression of multiple tumors (Peth et al. 2009). It deubiquitinates and stabilizes the androgen receptor (AR), which contributes to the progression and development of prostate and breast cancers (Liao et al. 2017, 2018). Furthermore, USP14 promotes cell growth, migration and invasion in gastric cancer by targeting vimentin, which is involved in EMT (Zhu et al. 2017). 
Wnt signaling regulates various homeostatic mechanisms; hence, its aberrant activation is observed in diverse cancers (Reya and Clevers 2005). USP14 is involved in Wnt signaling activation and $\beta$-catenin accumulation by regulating the ubiquitination of Dvl and its subsequent phosphorylation (Jung et al. 2013). In addition, a strong correlation has been observed between USP14 and $\beta$-catenin levels in colorectal cancer cells, and overexpressed USP14 could promote cell proliferation through the accumulation of $\beta$-catenin in NSCLC cells (Jung et al. 2013; Wu et al. 2013).

\section{UCH37}

Overexpression of $\mathrm{UCH} 37$ has been reported to be associated with a lower survival rate and an increased risk of cancer recurrence in cancer patients (Wang et al. 2014b). In endometrial cancer (EC), Wnt signaling is involved in cell survival, cell cycle, proliferation and metastasis. UCH37 activates Wnt signaling and affects the expression of its target genes, such as $\beta$-catenin, cyclin D1 and c-Myc, thereby increasing the cell growth of EC (Liu et al. 2020). It also regulates TGF- $\beta$ signaling, and aberrant TGF- $\beta$ signaling is closely related to the development of cancer. UCH37 deubiquitinates and stabilizes type I TGF- $\beta$ receptors by directly binding with SMAD7, which forms a complex with Smurf E3 ligase and induces degradation of the TGF- $\beta$ receptor (Wicks et al. 2005). The specific USP14 and UCH37 inhibitor b-AP15 suppresses cell growth via TGF- $\beta$ signaling and induces apoptosis in ovarian cancer cells (Fukui et al. 2019). UCH37 interacts with COPS5 to induce the ubiquitination and degradation of $\mathrm{p} 53$ and $\mathrm{p} 21$, promoting cell proliferation. Treatment with b-AP15 downregulates COPS5 levels and upregulates p53 levels, resulting in durable tumor regressions in p53-deficient mice (Ma et al. 2020). Furthermore, UCH37 knockdown results in reduced cell survival, increased caspase activity and a higher ratio of apoptotic regulator Bax/anti-apoptotic factor Bcl-2 in NSCLC cells (Chen et al. 2011b).

\section{RPN11}

Previous studies have shown that RPN11 expression is upregulated in various cancers such as breast cancer, MM and hepatocellular carcinoma (Luo et al. 2017). Downregulation of RPN11 induces apoptosis causing cell arrest in the G0-G1 phase, and ultimately leading to senescence by regulating the phosphorylation of cyclin-dependent kinases (CDKs) and retinoblastoma protein $(\mathrm{Rb})$ in cancer cells (Byrne et al. 2010). Conversely, overexpression of RPN11 promotes cancer progression by stabilizing the E2F transcription factor 1(E2F1) and promoting the expression of its target genes in hepatocellular carcinoma cells (Wang et al. 2015). Furthermore, RPN11 deubiquitinates ErbB2, leading to its accumulation, resulting in the promotion of cell growth and the inhibition of apoptosis of ErbB2-positive breast cancer cells (Liu et al. 2009; Song et al. 2017).

\section{Inhibitors of ubiquitinating enzymes-clinical trials}

As mentioned above, several E3 ligases have been considered as targets for novel anticancer drugs. However, clinical trials of inhibitors targeting E3 ligases are limited, because E3 ligases can act as both tumor suppressors and oncogenic proteins and their underlying mechanisms of regulating cellular processes are very complex (Zhang et al. 2020). Here, we introduce the inhibitors of ubiquitinating enzymes, especially E3 ligases that are currently in clinical studies.

\section{MLN4924 (pevonedistat)}

MLN4924 is a small molecule inhibitor of the NEDD8-activating enzyme (NAE) E1 enzyme (Soucy et al. 2009; Luo et al. 2012). This small molecule is an adenosine sulfamate analog that covalently binds to NAE to create a NEDD8MLN4924 adduct, consequently blocking neddylation of all cullin-RING ligases (CRLs), which regulate the destruction of many intracellular proteins. Inhibition of CRL neddylation suppresses cancer cell growth by increasing the levels of their substrates, which in turn triggers the DNA damage response, cell-cycle arrest, apoptosis and autophagy (Aubry et al. 2020). MLN4924 has been applied in several phase I clinical trials for certain solid tumors and hematologic malignancies and showed clinical activity in a phase I clinical trial of acute myelogenous leukemia (AML) (Swords et al. 2010). It is also known to inhibit angiogenesis during tumor development (Yao et al. 2014).

\section{MDM2 inhibitors}

MDM2 negatively regulates p53 activity, increasing cell survival in various cancers. The first small molecule inhibitor of MDM2 is Nutlin-3a, which inhibits the interaction between MDM2 and p53 (Vassilev et al. 2004). After optimization of Nutlin-3a, several derivatives were generated. Among them, RO-5503781 (Idasanutlin) is developed by Hoffmann-La Roche (Ding et al. 2013). This orally available inhibitor is proposed to treat glioblastoma (in preclinical trials), diffuse large B cell lymphoma, MM, prostate cancer (in a phase I/II clinical trial), and AML (in a phase III clinical trial combined with chemotherapy) (adisinsight.springer. com). However, this inhibitor was terminated in phase II clinical trials. In addition, MK- 8242 developed by Merch \& Co was terminated in phase I clinical trials for patients with advanced solid tumors and recurrent AML and liposarcomas. Besides that, SAR-405838, developed by Ascenta 
Therapeutics and Sanofi, CGM097 developed by Novartis, and DS3032b developed by Daichi Sankyo are all targeting the interaction of MDM2 and p53, and they are currently in phase I clinical trials for patients with advanced solid tumors, either alone or in combination with chemotherapy.

\section{Inhibitors of the proteasome-clinical trials}

Since the first proteasome inhibitor bortezomib was approved by the FDA for treating relapsed and refractory MM in 2003, the development of anticancer drugs targeting the proteasome among the components of the UPS has been the most active research field. All of the proteasome inhibitors developed so far play a role in inhibiting proteolytic activity by binding to the inner $\beta$-subunit of the $19 \mathrm{~S}$ RP of the proteasome.

\section{Bortezomib (BTZ, velcade)}

Bortezomib is a boronic acid-containing dipeptide, the first proteasome inhibitor introduced for the treatment of MM. This is a unique and reversible inhibitor of the $26 \mathrm{~S}$ proteasome that binds to the $\beta 5$ subunit of 19S RP and inhibits its chymotrypsin-like enzymatic activity, thus leading to the accumulation of polyubiquitinated proteins (Zhang et al. 2020). Incomplete and transient inhibition of the $26 S$ proteasome by BTZ causes apoptosis of myeloma cells by activation of caspases-8/9 (Hu et al. 2013). BTZ is currently used for the treatment of various cancers including $\mathrm{MM}$, relapsed mantle cell lymphoma, diffuse large B-cell lymphoma, colorectal cancer, and thyroid carcinoma. However, BTZ is doselimiting toxic and has been reported to cause multiple side effects, including pain, fatigue, peripheral neuropathy, myelosuppression, and cardiotoxicity. Additionally, about $60 \%$ of patients treated with BTZ developed resistance to this drug. To overcome BTZ resistance, the FDA approved the use of BTZ in combination with chemotherapeutic agents, such as Doxorubicin, Adriamycin, and Dexamethasone in clinical trials (Mata-Cantero et al. 2015; Zhang et al. 2020).

\section{Carfilzomib (CFZ, kyprolis)}

Carfilzomib is an epoxyketone peptide and is the second proteasome inhibitor approved by the FDA in 2012 for the treatment of patients with MM who have shown resistance to BTZ (Kuhn et al. 2007). CFZ inhibits the chymotrypsinlike activity of the proteasome more strongly than BTZ by forming a covalent and irreversible bond with catalytic subunits, predominantly $\beta 5$. Furthermore, it has a more selective mechanism of action and high chemical stability, resulting in fewer side effects compared to BTZ (Arastu-Kapur et al. 2011; Stewart et al. 2015). However, CFZ also has a problem: it does not dissolve well in water. For this reason, CFZ cannot be administered orally and a large amount of cyclodextrin is required for intravenous injection formulations (Zhang et al. 2020).

\section{Ixazomib (IXZ, ninlaro)}

In 2015, ixazomib received FDA approval as the first orally bioavailable proteasome inhibitor for the treatment of MM (Chauhan et al. 2011). It also binds to catalytic $\beta$-subunits and inhibits proteasome activity. Because of its great advantage that IXZ can be administered orally, its effectiveness is being studied as either a single or combined chemotherapeutic agents for a number of cancers. Indeed, it is known that IXZ does not affect the mitochondrial serine protease Htr/ Omi, which is an off-target of BTZ related to neuropathy, which is one of the side effects of BTZ (Zhang et al. 2020).

\section{Inhibitors of DUB-clinical trials}

DUBs have a high level of substrate specificity and a catalytic domain with properties similar to that of which it is attracting attention as a promising therapeutic target for cancers. (Eletr and Wilkinson 2014). Over the last few years, a large of small molecule inhibitors against DUBs have been reported, but only a few of them have entered into clinical trials for certain cancers.

\section{Pimozide}

Pimozide is a reversible inhibitor of the enzymatic activity of the USP1/UAF1 complex. It was originally discovered as an antipsychotic drug and approved by the FDA for the treatment of Tourette's syndrome. However, it has been revealed through HTS that pimozide inhibits USP1/UAF1, which acts synergistically with cisplatin to inhibit cell proliferation in cisplatin-resistant NSCLC cells (Chen et al. 2011a). This inhibitor is in a phase II clinical trial in patients with amyotrophic lateral sclerosis (Antao et al. 2020).

\section{Mitozantrone (novantrone)}

Mitozantrone was discovered through HTS of a large panel of FDA-approved compounds for inhibition of USP11 catalytic activity. This drug inhibits the DNA-damage repair (DDR) system induced by USP11, and it impacts pancreatic ductal adenocarcinoma (PDA) cell survival (Burkhart et al. 2013). In addition, mitozantrone inhibits TGF- $\beta 1$-induced phosphorylation of SMAD2/3 and the type I TGF- $\beta$ receptor through the reduction of type II TGF- $\beta$ receptor stability maintained by USP11 in lung fibroblast cells (Jacko et al. 2016). Currently, numerous phase I-IV clinical trials are 
Table 1 Inhibitors targeting UPS components in clinical trials

\begin{tabular}{|c|c|c|c|c|c|c|}
\hline Name & Target & Functions & $\begin{array}{c}\text { Clinical } \\
\text { status }\end{array}$ & Cancer types & Structure & Ref \\
\hline \multicolumn{7}{|c|}{ E1, E2, and E3 enzyme inhibitors } \\
\hline MLN4924 & NAE (E1) & $\begin{array}{l}\text { Blocks the } \\
\text { neddylation of all } \\
\text { CRLs, leading to } \\
\text { apoptosis in cancer } \\
\text { cells }\end{array}$ & $\begin{array}{l}\text { Phase III } \\
\text { Phase II } \\
\text { Phase I }\end{array}$ & $\begin{array}{l}\text { AML } \\
\text { LSCLC } \\
\text { Hepatocellular carcinoma } \\
\text { mesothelioma } \\
\text { Advanced solid tumor } \\
\text { MM } \\
\text { Lymphoma } \\
\text { AML } \\
\text { ALL } \\
\text { Melanoma }\end{array}$ & $\mathrm{C}_{21} \mathrm{H}_{25} \mathrm{~N}_{5} \mathrm{O}_{4} \mathrm{~S}$ & $\begin{array}{l}\text { www.clinical trials. gov } \\
\text { (Aubry et al. 2020) }\end{array}$ \\
\hline NSC697923 & $\begin{array}{l}\text { Ubc13- } \\
\text { Uev1A(E2) }\end{array}$ & $\begin{array}{l}\text { Blocks the formation } \\
\text { of the E2-Ub } \\
\text { thioester conjugate } \\
\text { and inhibits NF-kB } \\
\text { signaling }\end{array}$ & $\begin{array}{l}\text { Pre- } \\
\text { clinical }\end{array}$ & $\begin{array}{l}\text { Melanoma } \\
\text { B-cell lymphoma } \\
\text { Neuroblastoma } \\
\text { Colorectal cancer }\end{array}$ & $\mathrm{C}_{11} \mathrm{H}_{9} \mathrm{NO}_{5} \mathrm{~S}$ & $\begin{array}{l}\text { (Pulvino et al. 2012; } \\
\text { Zhang et al. 2020) }\end{array}$ \\
\hline SAR-405838 & $\begin{array}{l}\text { HDM2-p53 } \\
\text { interaction }\end{array}$ & $\begin{array}{l}\text { Selective } \\
\text { spirooxindole } \\
\text { derivative antagonist } \\
\text { of HDM2 } \\
\text { Leads to p53 } \\
\text { activation }\end{array}$ & Phase I & Solid tumor & $\mathrm{C}_{29} \mathrm{H}_{34} \mathrm{Cl}_{2} \mathrm{FN}_{\mathrm{Cl}} \mathrm{O}_{3}$ & $\begin{array}{l}\text { www.clinical trials. gov } \\
\text { (de Weger et al. 2019) }\end{array}$ \\
\hline CGM-097 & $\begin{array}{l}\text { HDM2-p53 } \\
\text { interaction }\end{array}$ & $\begin{array}{l}\text { Orally bioavailable } \\
\text { HDM2 antagonist } \\
\text { Leads to p53 } \\
\text { activation }\end{array}$ & Phase I & $\begin{array}{l}\text { Advanced solid tumor } \\
\text { with p53 wild type status }\end{array}$ & $\mathrm{C}_{38} \mathrm{H}_{47} \mathrm{ClN}_{4} \mathrm{O}_{4}$ & www.clinical trials. gov \\
\hline DS-3032 & $\begin{array}{l}\text { MDM2-p53 } \\
\text { interaction }\end{array}$ & $\begin{array}{l}\text { Orally bioavailable } \\
\text { HDM2 antagonist } \\
\text { Leads to p53 } \\
\text { activation }\end{array}$ & Phase I/II & AML & $\mathrm{C}_{30} \mathrm{H}_{34} \mathrm{Cl}_{2} \mathrm{FN}_{5} \mathrm{O}_{4}$ & www.clinical trials. gov \\
\hline AT-406 & $\begin{array}{l}\text { XIAP, } \\
\text { cIAP1/2 }\end{array}$ & $\begin{array}{l}\text { Orally active } \\
\text { antagonist of IAPs } \\
\text { Activates apoptosis }\end{array}$ & Phase I & $\begin{array}{l}\text { Lymphoma } \\
\text { Advanced solid tumor }\end{array}$ & $\mathrm{C}_{32} \mathrm{H}_{43} \mathrm{~N}_{5} \mathrm{O}_{4}$ & www.clinical trials. gov \\
\hline
\end{tabular}

under way targeting T-cell lymphoma, AML, multiple sclerosis, and breast cancer using mitozantrone (Antao et al. 2020).

\section{Papain-like cysteine protease (PLpro) inhibitors}

6-mercaptopurine (6MP) and 6-thioguaninie (6TG) are specific inhibitors of PLpro, a protease of the severe acute respiratory syndrome coronavirus (SARS-CoV). PLpro 
Table 1 (continued)

\begin{tabular}{|c|c|c|c|c|c|c|}
\hline Name & Target & Functions & $\begin{array}{l}\text { Clinical } \\
\text { status }\end{array}$ & Cancer types & Structure & Ref \\
\hline \multicolumn{7}{|c|}{ E1, E2, and E3 enzyme inhibitors } \\
\hline HGS-1029 & cIAP2 & & Phase I & Advanced solid tumor & $\mathrm{C}_{8} \mathrm{H}_{11} \mathrm{CIFNO}_{2} \mathrm{~S}$ & www.clinical trials. gov \\
\hline Compound $\# 25$ & SKP2 & $\begin{array}{l}\text { Suppresses SKP2 E3 } \\
\text { ligase activity }\end{array}$ & $\begin{array}{l}\text { Pre- } \\
\text { clinical }\end{array}$ & Prostate cancer & $\mathrm{C}_{24} \mathrm{H}$ & (Chan et al. 2013) \\
\hline NAHA & CDC20 & $\begin{array}{l}\text { Decreases CDC20 } \\
\text { expression and } \\
\text { inhibits tumor } \\
\text { proliferation }\end{array}$ & $\begin{array}{l}\text { Pre- } \\
\text { clinical }\end{array}$ & Breast cancer & $\begin{array}{l}\text { 2-[Benzyl-(2-nitro-benzenesulfonyl)- } \\
\text { amino]-N-hydroxy-3-methyl-Npropyl- } \\
\text { butyramide }\end{array}$ & (Wang et al. 2013) \\
\hline \multicolumn{7}{|c|}{ Proteasome inhibitors } \\
\hline Bortezomib & $\begin{array}{l}\text { Proteasome } \\
(\beta 5>\beta 1)\end{array}$ & $\begin{array}{l}\text { Inhibits the } \\
\text { chymotrypsin-like } \\
\text { activity of the } \\
\text { proteasome by } \\
\text { reversible binding to } \\
\text { the } \beta 5 \text { subunit and } \\
\text { leads to accumulation } \\
\text { of polyubiquitinated } \\
\text { proteins. }\end{array}$ & $\begin{array}{l}\text { Launched } \\
\text { Phase II } \\
\text { Phase I }\end{array}$ & $\begin{array}{l}\text { MM } \\
\text { Non-Hodkin's lymphoma } \\
\text { Other lymphoma } \\
\text { Leukemia } \\
\text { NSCLC } \\
\text { Kidney cancer } \\
\text { Mesothelioma } \\
\text { Soft tissue sarcoma } \\
\text { Glioma } \\
\text { Neuroblastoma } \\
\text { Head and neck cancer } \\
\text { Prostate cancer } \\
\text { Brain tumor } \\
\text { Breast cancer } \\
\text { Colorectal cancer } \\
\text { Ovarian cancer }\end{array}$ & $\mathrm{C}_{19} \mathrm{H}_{25} \mathrm{BN}_{4} \mathrm{O}_{4}$ & $\begin{array}{l}\text { www.clinical trials. gov } \\
\text { (Mata-Cantero et al. } \\
\text { 2015; Zhang et al. 2020) }\end{array}$ \\
\hline Carfilzomib & $\begin{array}{l}\text { Proteasome } \\
(\beta 5)\end{array}$ & $\begin{array}{l}\text { Inhibits } \\
\text { chymotrypsin-like } \\
\text { activity of } \\
\text { proteasome more } \\
\text { strongly than BTZ by } \\
\text { forming a covalent } \\
\text { and an irreversible } \\
\text { bond with catalytic } \\
\text { subunits, } \\
\text { predominantly } \beta 5\end{array}$ & $\begin{array}{l}\text { Launche } \\
\text { d } \\
\text { Phase II } \\
\text { Phase I }\end{array}$ & $\begin{array}{l}\text { MM } \\
\text { Non-Hodkin's lymphoma } \\
\text { Kidney cancer } \\
\text { Prostate cancer } \\
\text { Lung cancer } \\
\text { Ovarian cancer } \\
\text { Hodkin's lymphoma }\end{array}$ & $\mathrm{C}_{40} \mathrm{H}_{57} \mathrm{~N}_{5} \mathrm{O}_{7}$ & $\begin{array}{l}\text { www.clinical trials. gov } \\
\text { (Arastu-Kapur et al. } \\
\text { 2011; Stewart et al. } \\
\text { 2015) }\end{array}$ \\
\hline Ixazomib & $\begin{array}{l}\text { Proteasome } \\
(\beta 5>\beta 1)\end{array}$ & $\begin{array}{l}\text { First orally } \\
\text { bioavailable } \\
\text { proteasome inhibitor } \\
\text { Binds to catalytic } \beta \text { - } \\
\text { subunits and inhibits } \\
\text { proteasome activity }\end{array}$ & $\begin{array}{l}\text { Phase III } \\
\text { Phase II } \\
\text { Phase I }\end{array}$ & $\begin{array}{l}\text { MM } \\
\text { Lymphoma } \\
\text { Advanced solid tumors } \\
\text { ALL }\end{array}$ & $\begin{array}{c}\mathrm{C}_{14} \mathrm{H}_{19} \mathrm{BCl}_{2} \mathrm{~N}_{2} \mathrm{O}_{4} \\
\mathrm{Cl}\end{array}$ & $\begin{array}{l}\text { www.clinical trials. gov } \\
\text { (Chauhan et al. 2011) }\end{array}$ \\
\hline Delanzomib & $\begin{array}{l}\text { Proteasome } \\
(\beta 5, \beta 1, \beta 2)\end{array}$ & $\begin{array}{l}\text { Inhibits } \\
\text { chymotrypsin-like } \\
\text { activity of } \\
\text { proteasome and } \\
\text { represses the } \\
\text { proteasomal } \\
\text { degradation of } \\
\text { proteins, including } \\
\text { IאB- } \alpha \\
\end{array}$ & Phase I & Non-Hodkin's lymphoma & & $\begin{array}{l}\text { www.clinical trials. gov } \\
\text { www.cancer.gov }\end{array}$ \\
\hline
\end{tabular}


Table 1 (continued)

\begin{tabular}{|c|c|c|c|c|c|c|}
\hline Name & Target & Functions & $\begin{array}{c}\text { Clinical } \\
\text { status }\end{array}$ & Cancer types & Structure & Ref \\
\hline \multicolumn{7}{|c|}{ Proteasome inhibitors } \\
\hline Oprozomib & $\begin{array}{l}\text { Proteasome } \\
(\beta 5>\beta 1)\end{array}$ & $\begin{array}{l}\text { Structural homologue } \\
\text { of CFZ and orally } \\
\text { bioavailable inhibitor } \\
\text { Inhibits activity of } \\
\text { proteasome and } \\
\text { induces apoptosis }\end{array}$ & $\begin{array}{l}\text { Phase II } \\
\text { Phase I }\end{array}$ & $\begin{array}{l}\text { MM } \\
\text { Advanced solid tumor }\end{array}$ & $\mathrm{C}_{25} \mathrm{H}_{32} \mathrm{~N}_{4} \mathrm{O}_{7} \mathrm{~S}$ & $\begin{array}{l}\text { www.clinical trials. gov } \\
\text { www.cancer.gov }\end{array}$ \\
\hline Marizomib & $\begin{array}{l}\text { Proteasome } \\
(20 \text { S CS })\end{array}$ & $\begin{array}{l}\text { Irreversibly binds to } \\
\text { and inhibits the } 20 \mathrm{~S} \\
\text { catalytic core subunit } \\
\text { of the proteasome by } \\
\text { covalently modifying } \\
\text { its active site } \\
\text { threonine residues }\end{array}$ & $\begin{array}{l}\text { Phase III } \\
\text { Phase II } \\
\text { Phase I }\end{array}$ & $\begin{array}{l}\text { Glioblastoma } \\
\text { MM } \\
\text { Ependymoma } \\
\text { Glioma } \\
\text { NSCLC } \\
\text { Pancreatic cancer } \\
\text { Melanoma } \\
\text { Lymphoma }\end{array}$ & $\mathrm{C}_{15} \mathrm{H}_{2}$ & $\begin{array}{l}\text { www.clinical trials. gov } \\
\text { www.cancer.gov }\end{array}$ \\
\hline \multicolumn{7}{|c|}{ DUB inhibitors } \\
\hline Pimozide & $\begin{array}{l}\text { USP1 } \\
\text { Pan-DUBs }\end{array}$ & $\begin{array}{l}\text { Reversible, non- } \\
\text { competitive } \\
\text { inhibition of USP1 }\end{array}$ & $\begin{array}{l}\text { Pre- } \\
\text { clinical }\end{array}$ & $\begin{array}{l}\text { Melanoma } \\
\text { Breast cancer } \\
\text { LSCLC }\end{array}$ & $\mathrm{C}_{28} \mathrm{H}$ & (Chen et al. 2011a) \\
\hline Mitoxantrone & USP11 & Unknown & $\begin{array}{l}\text { Phase IV } \\
\text { Phase III } \\
\text { Phase I/II }\end{array}$ & $\begin{array}{l}\text { APL } \\
\text { AML } \\
\text { ALL } \\
\text { Lymphoma } \\
\text { Breast cancer } \\
\text { Prostate cancer } \\
\text { Leukemia } \\
\text { Prostate cancer } \\
\text { Breast cancer } \\
\text { Ovarian cancer }\end{array}$ & $\mathrm{C}_{22} \mathrm{H}_{28} \mathrm{~N}_{4} \mathrm{O}_{6}$ & $\begin{array}{l}\text { www.clinical trials. gov } \\
\text { (Burkhart et al. 2013) }\end{array}$ \\
\hline 6MP, 6TG & $\begin{array}{l}\text { PLpro, } \\
\text { USP14 }\end{array}$ & $\begin{array}{l}\text { Host antiviral } \\
\text { immune response } \\
\text { activation }\end{array}$ & $\begin{array}{l}\text { Launche } \\
\mathrm{d} \\
\text { Phase IV } \\
\text { Phase III } \\
\text { Phase II }\end{array}$ & $\begin{array}{l}\text { ALL } \\
\text { Lymphoma } \\
\text { Leukemia } \\
\text { lymphocytic acute } \\
\text { LAM } \\
\text { Lymphoma } \\
\text { Colorectal cancer } \\
\text { Breast cancer } \\
\text { Glioblastoma } \\
\end{array}$ & $\begin{array}{c}\mathrm{C}_{5} \mathrm{H}_{4} \mathrm{~N}_{4} \mathrm{~S} \\
\mathrm{~S}\end{array}$ & $\begin{array}{l}\text { www.clinical trials. gov } \\
\text { (Chen et al. 2009; Kemp } \\
\text { 2016) }\end{array}$ \\
\hline b-AP15 & $\begin{array}{l}\text { USP14 } \\
\text { UCHL5 }\end{array}$ & $\begin{array}{l}\text { Inhibition of 19S RP } \\
\text { deubiquitinating } \\
\text { activity }\end{array}$ & $\begin{array}{l}\text { Pre- } \\
\text { clinical }\end{array}$ & $\begin{array}{l}\text { MM } \\
\text { AML } \\
\text { Large B-cell lymphoma } \\
\text { Neuroblastoma } \\
\text { Prostate cancer } \\
\text { Ovarian cancer } \\
\text { Colorectal cancer } \\
\text { Lung cancer }\end{array}$ & $\mathrm{C}_{22} \mathrm{H}_{17} \mathrm{~N}_{3} \mathrm{O}_{6}$ & (Zhang et al. 2020) \\
\hline IU1 & USP14 & $\begin{array}{l}\text { Inhibition of } \\
\text { ubiquitin chain } \\
\text { trimming }\end{array}$ & $\begin{array}{l}\text { Pre- } \\
\text { clinical }\end{array}$ & Breast cancer & $\mathrm{C}_{18} \mathrm{H}_{21} \mathrm{FN}_{2} \mathrm{O}$ & (Xia et al. 2019) \\
\hline $\begin{array}{l}\text { Ortho- } \\
\text { phenanthroline } \\
\text { (OPA) }\end{array}$ & RPN11 & $\begin{array}{l}\text { Inhibits RPN11 } \\
\text { activity, but does not } \\
\text { affect proteasome } \\
\text { activity }\end{array}$ & $\begin{array}{l}\text { Pre- } \\
\text { clinical }\end{array}$ & $\begin{array}{l}\text { MM } \\
\text { Hepatocellular carcinoma } \\
\text { Cervical cancer } \\
\text { Breast cancer }\end{array}$ & & $\begin{array}{l}\text { (Guterman and } \\
\text { Glickman 2004; Song et } \\
\text { al. 2017) }\end{array}$ \\
\hline
\end{tabular}


Table 1 (continued)

\begin{tabular}{|l|l|l|l|l|l|l|}
\hline \multicolumn{1}{|c|}{ Name } & Target & \multicolumn{1}{c|}{ Functions } & $\begin{array}{l}\text { Clinical } \\
\text { status }\end{array}$ & Cancer types & DUB inhibitors \\
\hline $\begin{array}{l}\text { Quinolin-8-thiol } \\
\text { (8TQ) }\end{array}$ & RPN11 & $\begin{array}{l}\text { Targets zinc-bound } \\
\text { active site of RPN11 } \\
\text { and inhibits cell } \\
\text { proliferation }\end{array}$ & $\begin{array}{l}\text { Pre- } \\
\text { clinical }\end{array}$ & $\begin{array}{l}\text { Lung carcinoma } \\
\text { Colorectal cancer }\end{array}$ & (Li et al. 2017) \\
\hline P5091 & USP7 & $\begin{array}{l}\text { Enhanced } \\
\text { cytotoxicity via } \\
\text { MDM2-p53 signaling }\end{array}$ & $\begin{array}{l}\text { Pre- } \\
\text { clinical }\end{array}$ & MM & &
\end{tabular}

$A M L$ acute myeloid leukemia, $N S C L C$ non-small cell lung cancer, $A L L$ acute lymphoblastic leukemia, $M M$ multiple myeloma, $A P L$ acute promyelocytic leukemia

blocks IRF-dependent host antiviral immune responses by acting as a DUB that removes ubiquitin or ISG15 (another ubiquitin-like peptide) from host cell proteins (Kemp 2016). They have been used for the treatment of acute lymphatic leukemia and Non-Hodgkin's lymphoma (FDA-approved drugs). Also, they are currently in phase II-IV clinical trials in patients with leukemia, lymphoma, colorectal and breast cancers (Mata-Cantero et al. 2015). In addition, 6MP and 6TG show favorable binding energy to USP14, suggesting that they are potential inhibitors of USP14 (Chen et al. 2009).

\section{Conclusion}

Since the 2000s, the successful development of the proteasome inhibitor bortezomib as a MM treatment has marked the importance of the UPS in tumorigenesis, and numerous studies related to this are still ongoing. Not only the proteasome, but also the various components of the UPS play an important role in cancer progression, and it has been consistently demonstrated that small molecule inhibitors against them have an excellent effect on tumor suppression (Table 1). However, only a few UPS inhibitors are still in use in clinical practice, and many challenges including drug resistance, several side effects and limited efficacy in the treatment of solid tumors, are preventing them from being developed as successful cancer treatments. If these challenges can be overcome, the UPS will certainly become an attractive target for cancer therapeutics.

Acknowledgements This work was supported by a National Research Foundation of Korea (NRF) Grant funded by the Korean government (MSIP) (2020R1A4A4079494 and 2019R1A2C2004052).

\section{Compliance with ethical standards}

Conflict of interest All authors declares that they have no conflict of interest.

\section{References}

Abdul Rehman SA, Kristariyanto YA, Choi SY, Nkosi PJ, Weidlich S, Labib K, Hofmann K, Kulathu Y (2016) MINDY-1 is a member of an evolutionarily conserved and structurally distinct new family of deubiquitinating enzymes. Mol Cell 63(1):146155. https://doi.org/10.1016/j.molcel.2016.05.009

Amodio N, Scrima M, Palaia L, Salman AN, Quintiero A, Franco R, Botti G, Pirozzi P, Rocco G, De Rosa N, Viglietto G (2010) Oncogenic role of the E3 ubiquitin ligase NEDD4-1, a PTEN negative regulator, in non-small-cell lung carcinomas. Am J Pathol 177(5):2622-2634. https://doi.org/10.2353/ajpat h. 2010.091075

Antao AM, Tyagi A, Kim KS, Ramakrishna S (2020) Advances in deubiquitinating enzyme inhibition and applications in cancer therapeutics. Cancers (Basel). https://doi.org/10.3390/cance rs 12061579

Arastu-Kapur S, Anderl JL, Kraus M, Parlati F, Shenk KD, Lee SJ, Muchamuel T, Bennett MK, Driessen C, Ball AJ, Kirk CJ (2011) Nonproteasomal targets of the proteasome inhibitors bortezomib and carfilzomib: a link to clinical adverse events. Clin Cancer Res 17(9):2734-2743. https://doi. org/10.1158/1078-0432.CCR-10-1950

Arendt CS, Hochstrasser M (1999) Eukaryotic 20S proteasome catalytic subunit propeptides prevent active site inactivation by $\mathrm{N}$-terminal acetylation and promote particle assembly. EMBO J 18(13):3575-3585. https://doi.org/10.1093/emboj/18.13.3575

Asmamaw MD, Liu Y, Zheng YC, Shi XJ, Liu HM (2020) Skp2 in the ubiquitin-proteasome system: a comprehensive review. Med Res Rev 40(5):1920-1949. https://doi.org/10.1002/ med. 21675

Aubry A, Yu T, Bremner R (2020) Preclinical studies reveal MLN4924 is a promising new retinoblastoma therapy. Cell Death Discov 6:2. https://doi.org/10.1038/s41420-020-0237-8

Bedford L, Paine S, Sheppard PW, Mayer RJ, Roelofs J (2010) Assembly, structure, and function of the 26S proteasome. Trends Cell Biol 20(7):391-401. https://doi.org/10.1016/j.tcb.2010.03.007 
Bhattacharya S, Chakraborty D, Basu M, Ghosh MK (2018) Emerging insights into HAUSP (USP7) in physiology, cancer and other diseases. Signal Transduct Target Ther 3:17. https://doi. org/10.1038/s41392-018-0012-y

Bignell GR, Warren W, Seal S, Takahashi M, Rapley E, Barfoot R, Green H, Brown C, Biggs PJ, Lakhani SR, Jones C, Hansen J, Blair E, Hofmann B, Siebert R, Turner G, Evans DG, SchranderStumpel C, Beemer FA, van Den Ouweland A, Halley D, Delpech B, Cleveland MG, Leigh I, Leisti J, Rasmussen S (2000) Identification of the familial cylindromatosis tumour-suppressor gene. Nat Genet 25(2):160-165. https://doi.org/10.1038/76006

Braten O, Livneh I, Ziv T, Admon A, Kehat I, Caspi LH, Gonen H, Bercovich B, Godzik A, Jahandideh S, Jaroszewski L, Sommer T, Kwon YT, Guharoy M, Tompa P, Ciechanover A (2016) Numerous proteins with unique characteristics are degraded by the $26 \mathrm{~S}$ proteasome following monoubiquitination. Proc Natl Acad Sci USA 113(32):E4639-E4647. https://doi.org/10.1073/pnas.16086 44113

Burkhart RA, Peng Y, Norris ZA, Tholey RM, Talbott VA, Liang Q, Ai Y, Miller K, Lal S, Cozzitorto JA, Witkiewicz AK, Yeo CJ, Gehrmann M, Napper A, Winter JM, Sawicki JA, Zhuang Z, Brody JR (2013) Mitoxantrone targets human ubiquitin-specific peptidase 11 (USP11) and is a potent inhibitor of pancreatic cancer cell survival. Mol Cancer Res 11(8):901-911. https://doi. org/10.1158/1541-7786.MCR-12-0699

Byrne A, McLaren RP, Mason P, Chai L, Dufault MR, Huang Y, Liang B, Gans JD, Zhang M, Carter K, Gladysheva TB, Teicher BA, Biemann HP, Booker M, Goldberg MA, Klinger KW, Lillie J, Madden SL, Jiang Y (2010) Knockdown of human deubiquitinase PSMD14 induces cell cycle arrest and senescence. Exp Cell Res 316(2):258-271. https://doi.org/10.1016/j.yexcr.2009.08.018

Chan CH, Morrow JK, Li CF, Gao Y, Jin G, Moten A, Stagg LJ, Ladbury JE, Cai Z, Xu D, Logothetis CJ, Hung MC, Zhang S, Lin HK (2013) Pharmacological inactivation of Skp2 SCF ubiquitin ligase restricts cancer stem cell traits and cancer progression. Cell 154(3):556-568. https://doi.org/10.1016/j.cell.2013.06.048

Chauhan D, Tian Z, Zhou B, Kuhn D, Orlowski R, Raje N, Richardson P, Anderson KC (2011) In vitro and in vivo selective antitumor activity of a novel orally bioavailable proteasome inhibitor MLN9708 against multiple myeloma cells. Clin Cancer Res 17(16):5311-5321. https://doi.org/10.1158/1078-0432. CCR-11-0476

Chauhan D, Tian Z, Nicholson B, Kumar KG, Zhou B, Carrasco R, McDermott JL, Leach CA, Fulcinniti M, Kodrasov MP, Weinstock J, Kingsbury WD, Hideshima T, Shah PK, Minvielle S, Altun M, Kessler BM, Orlowski R, Richardson P, Munshi N, Anderson KC (2012) A small molecule inhibitor of ubiquitinspecific protease-7 induces apoptosis in multiple myeloma cells and overcomes bortezomib resistance. Cancer Cell 22(3):345358. https://doi.org/10.1016/j.ccr.2012.08.007

Chen X, Chou CY, Chang GG (2009) Thiopurine analogue inhibitors of severe acute respiratory syndrome-coronavirus papain-like protease, a deubiquitinating and deISGylating enzyme. Antivir Chem Chemother 19(4):151-156. https://doi.org/10.1177/09563 2020901900402

Chen J, Dexheimer TS, Ai Y, Liang Q, Villamil MA, Inglese J, Maloney DJ, Jadhav A, Simeonov A, Zhuang Z (2011a) Selective and cell-active inhibitors of the USP1/UAF1 deubiquitinase complex reverse cisplatin resistance in non-small cell lung cancer cells. Chem Biol 18(11):1390-1400. https://doi.org/10.1016/j. chembiol.2011.08.014

Chen Z, Niu X, Li Z, Yu Y, Ye X, Lu S, Chen Z (2011b) Effect of ubiquitin carboxy-terminal hydrolase 37 on apoptotic in A549 cells. Cell Biochem Funct 29(2):142-148. https://doi.org/10.1002/ cbf. 1734
Chen S, Xing H, Li S, Yu J, Li H, Liu S, Tian Z, Tang K, Rao Q, Wang M, Wang J (2015) Up-regulated A20 promotes proliferation, regulates cell cycle progression and induces chemotherapy resistance of acute lymphoblastic leukemia cells. Leuk Res 39(9):976-983. https://doi.org/10.1016/j.leukres.2015.06.004

Chu Y, Vahl JC, Kumar D, Heger K, Bertossi A, Wojtowicz E, Soberon V, Schenten D, Mack B, Reutelshofer M, Beyaert R, Amann K, van Loo G, Schmidt-Supprian M (2011) B cells lacking the tumor suppressor TNFAIP3/A20 display impaired differentiation and hyperactivation and cause inflammation and autoimmunity in aged mice. Blood 117(7):2227-2236. https://doi.org/10.1182/ blood-2010-09-306019

Ciechanover A (2005) Proteolysis: from the lysosome to ubiquitin and the proteasome. Nat Rev Mol Cell Biol 6(1):79-87. https://doi. org/10.1038/nrm 1552

da Silva SD, Cunha IW, Nishimoto IN, Soares FA, Carraro DM, Kowalski LP, Graner E (2009) Clinicopathological significance of ubiquitin-specific protease 2a (USP2a), fatty acid synthase (FASN), and ErbB2 expression in oral squamous cell carcinomas. Oral Oncol 45(10):e134-e139. https://doi.org/10.1016/j. oraloncology.2009.02.004

de Weger VA, de Jonge M, Langenberg MHG, Schellens JHM, Lolkema M, Varga A, Demers B, Thomas K, Hsu K, Tuffal G, Goodstal S, Mace S, Deutsch E (2019) A phase I study of the HDM2 antagonist SAR405838 combined with the MEK inhibitor pimasertib in patients with advanced solid tumours. Br J Cancer 120(3):286-293. https://doi.org/10.1038/s41416-018-0355-8

Ding Q, Zhang Z, Liu JJ, Jiang N, Zhang J, Ross TM, Chu XJ, Bartkovitz D, Podlaski F, Janson C, Tovar C, Filipovic ZM, Higgins B, Glenn K, Packman K, Vassilev LT, Graves B (2013) Discovery of RG7388, a potent and selective p53-MDM2 inhibitor in clinical development. J Med Chem 56(14):5979-5983. https://doi. org/10.1021/jm400487c

Dixit VM, Green S, Sarma V, Holzman LB, Wolf FW, O'Rourke K, Ward PA, Prochownik EV, Marks RM (1990) Tumor necrosis factor-alpha induction of novel gene products in human endothelial cells including a macrophage-specific chemotaxin. J Biol Chem 265(5):2973-2978

Dohda T, Maljukova A, Liu L, Heyman M, Grander D, Brodin D, Sangfelt O, Lendahl U (2007) Notch signaling induces SKP2 expression and promotes reduction of p27Kip1 in T-cell acute lymphoblastic leukemia cell lines. Exp Cell Res 313(14):31413152. https://doi.org/10.1016/j.yexcr.2007.04.027

Du Z, Song J, Wang Y, Zhao Y, Guda K, Yang S, Kao HY, Xu Y, Willis J, Markowitz SD, Sedwick D, Ewing RM, Wang Z (2010) DNMT1 stability is regulated by proteins coordinating deubiquitination and acetylation-driven ubiquitination. Sci Signal 3(146):ra80. https://doi.org/10.1126/scisignal.2001462

Eldridge AG, O'Brien T (2010) Therapeutic strategies within the ubiquitin proteasome system. Cell Death Differ 17(1):4-13. https:// doi.org/10.1038/cdd.2009.82

Eletr ZM, Wilkinson KD (2014) Regulation of proteolysis by human deubiquitinating enzymes. Biochim Biophys Acta 1843(1):114 128. https://doi.org/10.1016/j.bbamcr.2013.06.027

Fujii Y, Yada M, Nishiyama M, Kamura T, Takahashi H, Tsunematsu R, Susaki E, Nakagawa T, Matsumoto A, Nakayama KI (2006) Fbxw7 contributes to tumor suppression by targeting multiple proteins for ubiquitin-dependent degradation. Cancer Sci 97(8):729-736. https://doi.org/10.1111/j.1349-7006.2006.00239 .x

Fujita T, Liu W, Doihara H, Wan Y (2009) An in vivo study of Cdh1/ APC in breast cancer formation. Int J Cancer 125(4):826-836. https://doi.org/10.1002/ijc.24399

Fukuda M, Fukuda F, Horiuchi Y, Oku Y, Suzuki S, Kusama K, Sakashita H (2006) Expression of CYLD, NF-kappaB and 
NF-kappaB-related factors in salivary gland tumors. In Vivo 20(4):467-472

Fukuda M, Hiroi M, Suzuki S, Ohmori Y, Sakashita H (2008) Loss of CYLD might be associated with development of salivary gland tumors. Oncol Rep 19(6):1421-1427

Fukui S, Nagasaka K, Miyagawa Y, Kikuchi-Koike R, Kawata Y, Kanda R, Ichinose T, Sugihara T, Hiraike H, Wada-Hiraike O, Sasajima Y, Ayabe T (2019) The proteasome deubiquitinase inhibitor bAP15 downregulates TGF-beta/Smad signaling and induces apoptosis via UCHL5 inhibition in ovarian cancer. Oncotarget 10(57):5932-5948. https://doi.org/10.18632/oncot arget. 27219

Garcia-Higuera I, Manchado E, Dubus P, Canamero M, Mendez J, Moreno S, Malumbres M (2008) Genomic stability and tumour suppression by the APC/C cofactor Cdh1. Nat Cell Biol 10(7):802-811. https://doi.org/10.1038/ncb1742

Giovinazzi S, Morozov VM, Summers MK, Reinhold WC, Ishov AM (2013) USP7 and Daxx regulate mitosis progression and taxane sensitivity by affecting stability of Aurora-A kinase. Cell Death Differ 20(5):721-731. https://doi.org/10.1038/cdd.2012.169

Glickman MH, Rubin DM, Coux O, Wefes I, Pfeifer G, Cjeka Z, Baumeister W, Fried VA, Finley D (1998) A subcomplex of the proteasome regulatory particle required for ubiquitin-conjugate degradation and related to the COP9-signalosome and eIF3. Cell 94(5):615-623. https://doi.org/10.1016/s0092-8674(00)81603-7

Graner E, Tang D, Rossi S, Baron A, Migita T, Weinstein LJ, Lechpammer M, Huesken D, Zimmermann J, Signoretti S, Loda M (2004) The isopeptidase USP2a regulates the stability of fatty acid synthase in prostate cancer. Cancer Cell 5(3):253-261. https ://doi.org/10.1016/S1535-6108(04)00055-8

Greil C, Krohs J, Schnerch D, Follo M, Felthaus J, Engelhardt M, Wasch R (2016) The role of APC/C $(\mathrm{Cdh} 1)$ in replication stress and origin of genomic instability. Oncogene 35(23):3062-3070. https://doi.org/10.1038/onc.2015.367

Grim JE, Knoblaugh SE, Guthrie KA, Hagar A, Swanger J, Hespelt J, Delrow JJ, Small T, Grady WM, Nakayama KI, Clurman BE (2012) Fbw7 and p53 cooperatively suppress advanced and chromosomally unstable intestinal cancer. Mol Cell Biol 32(11):2160-2167. https://doi.org/10.1128/MCB.00305-12

Groll M, Ditzel L, Lowe J, Stock D, Bochtler M, Bartunik HD, Huber R (1997) Structure of 20S proteasome from yeast at 2.4 A resolution. Nature 386(6624):463-471. https://doi. org/10.1038/386463a0

Guo Q, Dong H, Liu X, Wang C, Liu N, Zhang J, Li B, Cao W, Ding T, Yang Z, Zhang X (2009) A20 is overexpressed in glioma cells and may serve as a potential therapeutic target. Expert Opin Ther Targets 13(7):733-741. https://doi. org/10.1517/14728220903045018

Gupta I, Singh K, Varshney NK, Khan S (2018) Delineating crosstalk mechanisms of the ubiquitin proteasome system that regulate apoptosis. Front Cell Dev Biol 6:11. https://doi.org/10.3389/ fcell.2018.00011

Guterman A, Glickman MH (2004) Complementary roles for Rpn11 and Ubp6 in deubiquitination and proteolysis by the proteasome. J Biol Chem 279(3):1729-1738. https://doi.org/10.1074/ jbc.M307050200

Hadjihannas MV, Bernkopf DB, Bruckner M, Behrens J (2012) Cell cycle control of Wnt/beta-catenin signalling by conductin/ axin2 through CDC20. EMBO Rep 13(4):347-354. https:// doi.org/10.1038/embor.2012.12

Han Y, Song C, Wang J, Tang H, Peng Z, Lu S (2018) HOXA13 contributes to gastric carcinogenesis through DHRS2 interacting with MDM2 and confers 5-FU resistance by a p53-dependent pathway. Mol Carcinog 57(6):722-734. https://doi. org/10.1002/mc.22793
Han T, Jiang S, Zheng H, Yin Q, Xie M, Little MR, Yin X, Chen M, Song SJ, Beg AA, Pandolfi PP, Wan L (2019) Interplay between $\mathrm{c}-\mathrm{Src}$ and the $\mathrm{APC} / \mathrm{C}$ co-activator $\mathrm{Cdh} 1$ regulates mammary tumorigenesis. Nat Commun 10(1):3716. https:// doi.org/10.1038/s41467-019-11618-7

Hayashi S, Ozaki T, Yoshida K, Hosoda M, Todo S, Akiyama S, Nakagawara A (2006) p73 and MDM2 confer the resistance of epidermoid carcinoma to cisplatin by blocking $\mathrm{p} 53$. Biochem Biophys Res Commun 347(1):60-66. https://doi.org/10.1016/j. bbrc.2006.06.095

Hayden MS, Ghosh S (2008) Shared principles in NF-kappaB signaling. Cell 132(3):344-362. https://doi.org/10.1016/j. cell.2008.01.020

He Y, Wang S, Tong J, Jiang S, Yang Y, Zhang Z, Xu Y, Zeng Y, Cao B, Moran MF, Mao X (2020) The deubiquitinase USP7 stabilizes Maf proteins to promote myeloma cell survival. J Biol Chem 295(7):2084-2096. https://doi.org/10.1074/jbc. RA119.010724

Hellerbrand C, Bumes E, Bataille F, Dietmaier W, Massoumi R, Bosserhoff AK (2007) Reduced expression of CYLD in human colon and hepatocellular carcinomas. Carcinogenesis 28(1):2127. https://doi.org/10.1093/carcin/bgl081

Hermanns T, Pichlo C, Woiwode I, Klopffleisch K, Witting KF, Ovaa H, Baumann U, Hofmann K (2018) A family of unconventional deubiquitinases with modular chain specificity determinants. Nat Commun 9(1):799. https://doi.org/10.1038/s41467-018-03148-5

Hershko DD, Shapira M (2006) Prognostic role of p27Kip1 deregulation in colorectal cancer. Cancer 107(4):668-675. https://doi. org/10.1002/cncr.22073

Hoesel B, Schmid JA (2013) The complexity of NF-kappaB signaling in inflammation and cancer. Mol Cancer 12:86. https://doi. org/10.1186/1476-4598-12-86

Hovelmeyer N, Reissig S, Xuan NT, Adams-Quack P, Lukas D, Nikolaev A, Schluter D, Waisman A (2011) A20 deficiency in B cells enhances B-cell proliferation and results in the development of autoantibodies. Eur J Immunol 41(3):595-601. https:// doi.org/10.1002/eji.201041313

Hu J, Van Valckenborgh E, Xu D, Menu E, De Raeve H, De Bruyne E, Xu S, Van Camp B, Handisides D, Hart CP, Vanderkerken K (2013) Synergistic induction of apoptosis in multiple myeloma cells by bortezomib and hypoxia-activated prodrug TH-302, in vivo and in vitro. Mol Cancer Ther 12(9):1763-1773. https:// doi.org/10.1158/1535-7163.MCT-13-0123

Huang H, Regan KM, Wang F, Wang D, Smith DI, van Deursen JM, Tindall DJ (2005) Skp2 inhibits FOXO1 in tumor suppression through ubiquitin-mediated degradation. Proc Natl Acad Sci USA 102(5):1649-1654. https://doi.org/10.1073/pnas.04067 89102

Huang HC, Shi J, Orth JD, Mitchison TJ (2009) Evidence that mitotic exit is a better cancer therapeutic target than spindle assembly. Cancer Cell 16(4):347-358. https://doi.org/10.1016/j. ccr.2009.08.020

Huang ZJ, Zhu JJ, Yang XY, Biskup E (2017) NEDD4 promotes cell growth and migration via PTEN/PI3K/AKT signaling in hepatocellular carcinoma. Oncol Lett 14(3):2649-2656. https://doi. org/10.3892/ol.2017.6532

Huang X, Gu H, Zhang E, Chen Q, Cao W, Yan H, Chen J, Yang L, Lv N, He J, Yi Q, Cai Z (2020) The NEDD4-1 E3 ubiquitin ligase: a potential molecular target for bortezomib sensitivity in multiple myeloma. Int J Cancer 146(7):1963-1978. https://doi. org/10.1002/ijc.32615

Huibregtse JM, Scheffner M, Beaudenon S, Howley PM (1995) A family of proteins structurally and functionally related to the E6-AP ubiquitin-protein ligase. Proc Natl Acad Sci USA 92(11):5249. https://doi.org/10.1073/pnas.92.7.2563 
Hutti JE, Shen RR, Abbott DW, Zhou AY, Sprott KM, Asara JM, Hahn WC, Cantley LC (2009) Phosphorylation of the tumor suppressor CYLD by the breast cancer oncogene IKKepsilon promotes cell transformation. Mol Cell 34(4):461-472. https:// doi.org/10.1016/j.molcel.2009.04.031

Ibusuki M, Yamamoto Y, Shinriki S, Ando Y, Iwase H (2011) Reduced expression of ubiquitin ligase FBXW7 mRNA is associated with poor prognosis in breast cancer patients. Cancer Sci 102(2):439445. https://doi.org/10.1111/j.1349-7006.2010.01801.x

Iwatsuki M, Mimori K, Ishii H, Yokobori T, Takatsuno Y, Sato T, Toh H, Onoyama I, Nakayama KI, Baba H, Mori M (2010) Loss of FBXW7, a cell cycle regulating gene, in colorectal cancer: clinical significance. Int J Cancer 126(8):1828-1837. https://doi. org/10.1002/ijc. 24879

Jacko AM, Nan L, Li S, Tan J, Zhao J, Kass DJ, Zhao Y (2016) Deubiquitinating enzyme, USP11, promotes transforming growth factor beta-1 signaling through stabilization of transforming growth factor beta receptor II. Cell Death Dis 7(11):e2474. https ://doi.org/10.1038/cddis.2016.371

Jung H, Kim BG, Han WH, Lee JH, Cho JY, Park WS, Maurice MM, Han JK, Lee MJ, Finley D, Jho EH (2013) Deubiquitination of dishevelled by Usp14 is required for Wnt signaling. Oncogenesis 2:e64. https://doi.org/10.1038/oncsis.2013.28

Kemp M (2016) Recent advances in the discovery of deubiquitinating enzyme inhibitors. Prog Med Chem 55:149-192. https://doi. org/10.1016/bs.pmch.2015.10.002

Kidokoro T, Tanikawa C, Furukawa Y, Katagiri T, Nakamura Y, Matsuda K (2008) CDC20, a potential cancer therapeutic target, is negatively regulated by $\mathrm{p} 53$. Oncogene $27(11): 1562-1571$. https ://doi.org/10.1038/sj.onc.1210799

Kim J, Kim WJ, Liu Z, Loda M, Freeman MR (2012) The ubiquitinspecific protease USP2a enhances tumor progression by targeting cyclin A1 in bladder cancer. Cell Cycle 11(6):1123-1130. https ://doi.org/10.4161/cc.11.6.19550

Koepp DM, Schaefer LK, Ye X, Keyomarsi K, Chu C, Harper JW, Elledge SJ (2001) Phosphorylation-dependent ubiquitination of cyclin E by the SCFFbw7 ubiquitin ligase. Science 294(5540):173-177. https://doi.org/10.1126/science.1065203

Komander D, Clague MJ, Urbe S (2009) Breaking the chains: structure and function of the deubiquitinases. Nat Rev Mol Cell Biol 10(8):550-563. https://doi.org/10.1038/nrm2731

Kondo S, Barnett GH, Hara H, Morimura T, Takeuchi J (1995) MDM2 protein confers the resistance of a human glioblastoma cell line to cisplatin-induced apoptosis. Oncogene 10(10):2001-2006

Kuhn DJ, Chen Q, Voorhees PM, Strader JS, Shenk KD, Sun CM, Demo SD, Bennett MK, van Leeuwen FW, Chanan-Khan AA, Orlowski RZ (2007) Potent activity of carfilzomib, a novel, irreversible inhibitor of the ubiquitin-proteasome pathway, against preclinical models of multiple myeloma. Blood 110(9):32813290. https://doi.org/10.1182/blood-2007-01-065888

Lee MJ, Lee BH, Hanna J, King RW, Finley D (2011) Trimming of ubiquitin chains by proteasome-associated deubiquitinating enzymes. Mol Cell Proteom. https://doi.org/10.1074/mcp. R110.003871

Lee JH, Jung SM, Yang KM, Bae E, Ahn SG, Park JS, Seo D, Kim M, Ha J, Lee J, Kim JH, Kim JH, Ooshima A, Park J, Shin D, Lee YS, Lee S, van Loo G, Jeong J, Kim SJ, Park SH (2017) A20 promotes metastasis of aggressive basal-like breast cancers through multi-monoubiquitylation of Snail1. Nat Cell Biol 19(10):1260-1273. https://doi.org/10.1038/ncb3609

Li J, Yakushi T, Parlati F, Mackinnon AL, Perez C, Ma Y, Carter KP, Colayco S, Magnuson G, Brown B, Nguyen K, Vasile S, Suyama E, Smith LH, Sergienko E, Pinkerton AB, Chung TDY, Palmer AE, Pass I, Hess S, Cohen SM, Deshaies RJ (2017) Capzimin is a potent and specific inhibitor of proteasome isopeptidase Rpn11.
Nat Chem Biol 13(5):486-493. https://doi.org/10.1038/nchem bio. 2326

Li C, Du L, Ren Y, Liu X, Jiao Q, Cui D, Wen M, Wang C, Wei G, Wang Y, Ji A, Wang Q (2019) SKP2 promotes breast cancer tumorigenesis and radiation tolerance through PDCD4 ubiquitination. J Exp Clin Cancer Res 38(1):76. https://doi.org/10.1186/ s13046-019-1069-3

Liang J, Saad Y, Lei T, Wang J, Qi D, Yang Q, Kolattukudy PE, Fu M (2010) MCP-induced protein 1 deubiquitinates TRAF proteins and negatively regulates JNK and NF-kappaB signaling. J Exp Med 207(13):2959-2973. https://doi.org/10.1084/jem.20092641

Liao Y, Liu N, Hua X, Cai J, Xia X, Wang X, Huang H, Liu J (2017) Proteasome-associated deubiquitinase ubiquitin-specific protease 14 regulates prostate cancer proliferation by deubiquitinating and stabilizing androgen receptor. Cell Death Dis 8(2):e2585. https ://doi.org/10.1038/cddis.2016.477

Liao Y, Xia X, Liu N, Cai J, Guo Z, Li Y, Jiang L, Dou QP, Tang D, Huang H, Liu J (2018) Growth arrest and apoptosis induction in androgen receptor-positive human breast cancer cells by inhibition of USP14-mediated androgen receptor deubiquitination. Oncogene 37(14):1896-1910. https://doi.org/10.1038/s4138 8-017-0069-z

Liu H, Buus R, Clague MJ, Urbe S (2009) Regulation of ErbB2 receptor status by the proteasomal DUB POH1. PLoS ONE 4(5):e5544. https://doi.org/10.1371/journal.pone.0005544

Liu PY, Xu N, Malyukova A, Scarlett CJ, Sun YT, Zhang XD, Ling D, Su SP, Nelson C, Chang DK, Koach J, Tee AE, Haber M, Norris MD, Toon C, Rooman I, Xue C, Cheung BB, Kumar S, Marshall GM, Biankin AV, Liu T (2013) The histone deacetylase SIRT2 stabilizes Myc oncoproteins. Cell Death Differ 20(3):503-514. https://doi.org/10.1038/cdd.2012.147

Liu D, Song Z, Wang X, Ouyang L (2020) Ubiquitin C-terminal hydrolase L5 (UCHL5) accelerates the growth of endometrial cancer via activating the Wnt/beta-catenin signaling pathway. Front Oncol 10:865. https://doi.org/10.3389/fonc.2020.00865

Lorick KL, Jensen JP, Fang S, Ong AM, Hatakeyama S, Weissman AM (1999) RING fingers mediate ubiquitin-conjugating enzyme (E2)-dependent ubiquitination. Proc Natl Acad Sci USA 96(20):11364-11369. https://doi.org/10.1073/pnas.96.20.11364

Luo Z, Pan Y, Jeong LS, Liu J, Jia L (2012) Inactivation of the Cullin (CUL)-RING E3 ligase by the NEDD8-activating enzyme inhibitor MLN4924 triggers protective autophagy in cancer cells. Autophagy 8(11):1677-1679. https://doi.org/10.4161/auto.21484

Luo G, Hu N, Xia X, Zhou J, Ye C (2017) RPN11 deubiquitinase promotes proliferation and migration of breast cancer cells. Mol Med Rep 16(1):331-338. https://doi.org/10.3892/mmr.2017.6587

Ma YS, Wang XF, Yu F, Wu TM, Liu JB, Zhang YJ, Xia Q, Jiang ZY, Lin QL, Fu D (2020) Inhibition of USP14 and UCH37 deubiquitinating activity by b-AP15 as a potential therapy for tumors with p53 deficiency. Signal Transduct Target Ther 5(1):30. https ://doi.org/10.1038/s41392-020-0143-9

Manchado E, Guillamot M, de Carcer G, Eguren M, Trickey M, GarciaHiguera I, Moreno S, Yamano H, Canamero M, Malumbres M (2010) Targeting mitotic exit leads to tumor regression in vivo: modulation by Cdk1, Mastl, and the PP2A/B55alpha, delta phosphatase. Cancer Cell 18(6):641-654. https://doi.org/10.1016/j. ccr.2010.10.028

Mani A, Gelmann EP (2005) The ubiquitin-proteasome pathway and its role in cancer. J Clin Oncol 23(21):4776-4789. https://doi. org/10.1200/JCO.2005.05.081

Mao JH, Perez-Losada J, Wu D, Delrosario R, Tsunematsu R, Nakayama KI, Brown K, Bryson S, Balmain A (2004) Fbxw7/Cdc4 is a p53-dependent, haploinsufficient tumour suppressor gene. Nature 432(7018):775-779. https://doi.org/10.1038/nature03155

Massoumi R, Kuphal S, Hellerbrand C, Haas B, Wild P, Spruss T, Pfeifer A, Fassler R, Bosserhoff AK (2009) Down-regulation 
of CYLD expression by snail promotes tumor progression in malignant melanoma. J Exp Med 206(1):221-232. https://doi. org/10.1084/jem.20082044

Mata-Cantero L, Lobato-Gil S, Aillet F, Lang V, Rodriguez MS (2015) The ubiquitin-proteasome system (UPS) as a cancer drug target: emerging mechanisms and therapeutics. In: Wondrak G (ed) Stress response pathways in cancer. Springer, Dordrecht, pp 225-264. https://doi.org/10.1007/978-94-017-9421-3_11

McKeon JE, Sha D, Li L, Chin LS (2015) Parkin-mediated K63-polyubiquitination targets ubiquitin C-terminal hydrolase L1 for degradation by the autophagy-lysosome system. Cell Mol Life Sci 72(9):1811-1824. https://doi.org/10.1007/s00018-014-1781-2

Moberg KH, Bell DW, Wahrer DC, Haber DA, Hariharan IK (2001) Archipelago regulates Cyclin E levels in Drosophila and is mutated in human cancer cell lines. Nature 413(6853):311-316. https://doi.org/10.1038/35095068

Nakagawa T, Nakayama K (2015) Protein monoubiquitylation: targets and diverse functions. Genes Cells 20(7):543-562. https://doi. org $/ 10.1111 /$ gtc. 12250

Nguyen LK, Kolch W, Kholodenko BN (2013) When ubiquitination meets phosphorylation: a systems biology perspective of EGFR/MAPK signalling. Cell Commun Signal 11:52. https:// doi.org/10.1186/1478-811X-11-52

Novellasdemunt L, Foglizzo V, Cuadrado L, Antas P, Kucharska A, Encheva V, Snijders AP, Li VSW (2017) USP7 Is a tumor-specific WNT activator for APC-mutated colorectal cancer by mediating beta-catenin deubiquitination. Cell Rep 21(3):612-627. https://doi.org/10.1016/j.celrep.2017.09.072

Park J, Cho J, Kim EE, Song EJ (2019) Deubiquitinating enzymes: a critical regulator of mitosis. Int J Mol Sci. https://doi. org/10.3390/ijms20235997

Patel K, Ahmed ZS, Huang X, Yang Q, Ekinci E, Neslund-Dudas CM, Mitra B, Elnady FA, Ahn YH, Yang H, Liu J, Dou QP (2018) Discovering proteasomal deubiquitinating enzyme inhibitors for cancer therapy: lessons from rational design, nature and old drug reposition. Future Med Chem 10(17):2087-2108. https:// doi.org/10.4155/fmc-2018-0091

Peth A, Besche HC, Goldberg AL (2009) Ubiquitinated proteins activate the proteasome by binding to Usp14/Ubp6, which causes 20S gate opening. Mol Cell 36(5):794-804. https://doi. org/10.1016/j.molcel.2009.11.015

Pohl C, Dikic I (2019) Cellular quality control by the ubiquitin-proteasome system and autophagy. Science 366(6467):818-822. https ://doi.org/10.1126/science.aax3769

Priolo C, Tang D, Brahamandan M, Benassi B, Sicinska E, Ogino S, Farsetti A, Porrello A, Finn S, Zimmermann J, Febbo P, Loda M (2006) The isopeptidase USP2a protects human prostate cancer from apoptosis. Cancer Res 66(17):8625-8632. https://doi. org/10.1158/0008-5472.CAN-06-1374

Pulvino M, Liang Y, Oleksyn D, DeRan M, Van Pelt E, Shapiro J, Sanz I, Chen L, Zhao J (2012) Inhibition of proliferation and survival of diffuse large B-cell lymphoma cells by a small-molecule inhibitor of the ubiquitin-conjugating enzyme Ubc13-Uev1A. Blood 120(8):1668-1677. https://doi.org/10.1182/blood-2012$02-406074$

Rajagopalan H, Jallepalli PV, Rago C, Velculescu VE, Kinzler KW, Vogelstein B, Lengauer C (2004) Inactivation of hCDC4 can cause chromosomal instability. Nature 428(6978):77-81. https ://doi.org/10.1038/nature02313

Reiley W, Zhang M, Wu X, Granger E, Sun SC (2005) Regulation of the deubiquitinating enzyme CYLD by IkappaB kinase gammadependent phosphorylation. Mol Cell Biol 25(10):3886-3895. https://doi.org/10.1128/MCB.25.10.3886-3895.2005

Reya T, Clevers H (2005) Wnt signalling in stem cells and cancer. Nature 434(7035):843-850. https://doi.org/10.1038/nature03319
Reyes-Turcu FE, Ventii KH, Wilkinson KD (2009) Regulation and cellular roles of ubiquitin-specific deubiquitinating enzymes. Annu Rev Biochem 78:363-397. https://doi.org/10.1146/annurev.bioch em.78.082307.091526

Sato A, Sunayama J, Matsuda K, Seino S, Suzuki K, Watanabe E, Tachibana K, Tomiyama A, Kayama T, Kitanaka C (2011) MEKERK signaling dictates DNA-repair gene MGMT expression and temozolomide resistance of stem-like glioblastoma cells via the MDM2-p53 axis. Stem Cells 29(12):1942-1951. https://doi. org/10.1002/stem.753

Scheffner M, Nuber U, Huibregtse JM (1995) Protein ubiquitination involving an E1-E2-E3 enzyme ubiquitin thioester cascade. Nature 373(6509):81-83. https://doi.org/10.1038/373081a0

Selvaraju K, Mazurkiewicz M, Wang X, Gullbo J, Linder S, D’Arcy $\mathrm{P}$ (2015) Inhibition of proteasome deubiquitinase activity: a strategy to overcome resistance to conventional proteasome inhibitors? Drug Resist Updates 21-22:20-29. https://doi. org/10.1016/j.drup.2015.06.001

Senft D, Qi J, Ronai ZA (2018) Ubiquitin ligases in oncogenic transformation and cancer therapy. Nat Rev Cancer 18(2):69-88. https ://doi.org/10.1038/nrc.2017.105

Shabek N, Iwai K, Ciechanover A (2007) Ubiquitin is degraded by the ubiquitin system as a monomer and as part of its conjugated target. Biochem Biophys Res Commun 363(2):425-431. https:// doi.org/10.1016/j.bbrc.2007.08.185

Shabek N, Herman-Bachinsky Y, Ciechanover A (2009) Ubiquitin degradation with its substrate, or as a monomer in a ubiquitination-independent mode, provides clues to proteasome regulation. Proc Natl Acad Sci USA 106(29):11907-11912. https://doi. org/10.1073/pnas.0905746106

Shabek N, Herman-Bachinsky Y, Buchsbaum S, Lewinson O, HajYahya M, Hejjaoui M, Lashuel HA, Sommer T, Brik A, Ciechanover A (2012) The size of the proteasomal substrate determines whether its degradation will be mediated by mono- or polyubiquitylation. Mol Cell 48(1):87-97. https://doi.org/10.1016/j.molce 1.2012.07.011

Shan J, Zhao W, Gu W (2009) Suppression of cancer cell growth by promoting cyclin D1 degradation. Mol Cell 36(3):469-476. https ://doi.org/10.1016/j.molcel.2009.10.018

Shangary S, Wang S (2008) Targeting the MDM2-p53 interaction for cancer therapy. Clin Cancer Res 14(17):5318-5324. https://doi. org/10.1158/1078-0432.CCR-07-5136

Sheng W, Dong M, Chen C, Wang Z, Li Y, Wang K, Li Y, Zhou J (2017) Cooperation of Musashi-2, Numb, MDM2, and P53 in drug resistance and malignant biology of pancreatic cancer. FASEB J 31(6):2429-2438. https://doi.org/10.1096/fj.20160 1240R

Song MS, Salmena L, Carracedo A, Egia A, Lo-Coco F, Teruya-Feldstein J, Pandolfi PP (2008) The deubiquitinylation and localization of PTEN are regulated by a HAUSP-PML network. Nature 455(7214):813-817. https://doi.org/10.1038/nature07290

Song Y, Li S, Ray A, Das DS, Qi J, Samur MK, Tai YT, Munshi N, Carrasco RD, Chauhan D, Anderson KC (2017) Blockade of deubiquitylating enzyme Rpn11 triggers apoptosis in multiple myeloma cells and overcomes bortezomib resistance. Oncogene 36(40):5631-5638. https://doi.org/10.1038/onc.2017.172

Soucy TA, Smith PG, Milhollen MA, Berger AJ, Gavin JM, Adhikari S, Brownell JE, Burke KE, Cardin DP, Critchley S, Cullis CA, Doucette A, Garnsey JJ, Gaulin JL, Gershman RE, Lublinsky AR, McDonald A, Mizutani H, Narayanan U, Olhava EJ, Peluso S, Rezaei M, Sintchak MD, Talreja T, Thomas MP, Traore T, Vyskocil S, Weatherhead GS, Yu J, Zhang J, Dick LR, Claiborne CF, Rolfe M, Bolen JB, Langston SP (2009) An inhibitor of NEDD8-activating enzyme as a new approach to treat cancer. Nature 458(7239):732-736. https://doi.org/10.1038/nature07884 
Stevenson LF, Sparks A, Allende-Vega N, Xirodimas DP, Lane DP, Saville MK (2007) The deubiquitinating enzyme USP2a regulates the p53 pathway by targeting Mdm2. EMBO J 26(4):976986. https://doi.org/10.1038/sj.emboj.7601567

Stewart AK, Rajkumar SV, Dimopoulos MA, Masszi T, Spicka I, Oriol A, Hajek R, Rosinol L, Siegel DS, Mihaylov GG, GoranovaMarinova V, Rajnics P, Suvorov A, Niesvizky R, Jakubowiak AJ, San-Miguel JF, Ludwig H, Wang M, Maisnar V, Minarik J, Bensinger WI, Mateos MV, Ben-Yehuda D, Kukreti V, Zojwalla $\mathrm{N}$, Tonda ME, Yang X, Xing B, Moreau P, Palumbo A, Investigators A (2015) Carfilzomib, lenalidomide, and dexamethasone for relapsed multiple myeloma. N Engl J Med 372(2):142-152. https://doi.org/10.1056/NEJMoa1411321

Strohmaier H, Spruck CH, Kaiser P, Won KA, Sangfelt O, Reed SI (2001) Human F-box protein hCdc4 targets cyclin E for proteolysis and is mutated in a breast cancer cell line. Nature 413(6853):316-322. https://doi.org/10.1038/35095076

Suzuki A, Toi M, Yamamoto Y, Saji S, Muta M, Tominaga T (1998) Role of MDM2 overexpression in doxorubicin resistance of breast carcinoma. Jpn J Cancer Res 89(2):221-227. https://doi. org/10.1111/j.1349-7006.1998.tb00552.x

Swords RT, Kelly KR, Smith PG, Garnsey JJ, Mahalingam D, Medina E, Oberheu K, Padmanabhan S, O’Dwyer M, Nawrocki ST, Giles FJ, Carew JS (2010) Inhibition of NEDD8-activating enzyme: a novel approach for the treatment of acute myeloid leukemia. Blood 115(18):3796-3800. https://doi.org/10.1182/blood-200911-254862

Tauriello DV, Haegebarth A, Kuper I, Edelmann MJ, Henraat M, Canninga-van Dijk MR, Kessler BM, Clevers H, Maurice MM (2010) Loss of the tumor suppressor CYLD enhances Wnt/ beta-catenin signaling through K63-linked ubiquitination of Dvl. Mol Cell 37(5):607-619. https://doi.org/10.1016/j.molce 1.2010 .01 .035

Tavana O, Gu W (2017) Modulation of the p53/MDM2 interplay by HAUSP inhibitors. J Mol Cell Biol 9(1):45-52. https://doi. org/10.1093/jmcb/mjw049

Tavares RM, Turer EE, Liu CL, Advincula R, Scapini P, Rhee L, Barrera J, Lowell CA, Utz PJ, Malynn BA, Ma A (2010) The ubiquitin modifying enzyme A20 restricts B cell survival and prevents autoimmunity. Immunity 33(2):181-191. https://doi. org/10.1016/j.immuni.2010.07.017

Vassilev LT, Vu BT, Graves B, Carvajal D, Podlaski F, Filipovic Z, Kong N, Kammlott U, Lukacs C, Klein C, Fotouhi N, Liu EA (2004) In vivo activation of the p53 pathway by small-molecule antagonists of MDM2. Science 303(5659):844-848. https://doi. org/10.1126/science. 1092472

Verma R, Aravind L, Oania R, McDonald WH, Yates JR 3rd, Koonin EV, Deshaies RJ (2002) Role of Rpn11 metalloprotease in deubiquitination and degradation by the $26 \mathrm{~S}$ proteasome. Science 298(5593):611-615. https://doi.org/10.1126/science.1075898

Voges D, Zwickl P, Baumeister W (1999) The 26S proteasome: a molecular machine designed for controlled proteolysis. Annu Rev Biochem 68:1015-1068. https://doi.org/10.1146/annur ev.biochem.68.1.1015

Wan L, Chen M, Cao J, Dai X, Yin Q, Zhang J, Song SJ, Lu Y, Liu J, Inuzuka H, Katon JM, Berry K, Fung J, Ng C, Liu P, Song MS, Xue L, Bronson RT, Kirschner MW, Cui R, Pandolfi PP, Wei W (2017) The APC/C E3 ligase complex activator FZR1 restricts BRAF oncogenic function. Cancer Discov 7(4):424-441. https ://doi.org/10.1158/2159-8290.CD-16-0647

Wang L, Baiocchi RA, Pal S, Mosialos G, Caligiuri M, Sif S (2005) The BRG1- and hBRM-associated factor BAF57 induces apoptosis by stimulating expression of the cylindromatosis tumor suppressor gene. Mol Cell Biol 25(18):7953-7965. https://doi. org/10.1128/MCB.25.18.7953-7965.2005
Wang X, Trotman LC, Koppie T, Alimonti A, Chen Z, Gao Z, Wang J, Erdjument-Bromage H, Tempst P, Cordon-Cardo C, Pandolfi PP, Jiang X (2007) NEDD4-1 is a proto-oncogenic ubiquitin ligase for PTEN. Cell 128(1):129-139. https://doi.org/10.1016/j. cell.2006.11.039

Wang X, Shi Y, Wang J, Huang G, Jiang X (2008) Crucial role of the C-terminus of PTEN in antagonizing NEDD4-1-mediated PTEN ubiquitination and degradation. Biochem J 414(2):221-229. https ://doi.org/10.1042/BJ20080674

Wang Z, Wan L, Zhong J, Inuzuka H, Liu P, Sarkar FH, Wei W (2013) Cdc20: a potential novel therapeutic target for cancer treatment. Curr Pharm Des 19(18):3210-3214. https://doi. org/10.2174/1381612811319180005

Wang CL, Wang JY, Liu ZY, Ma XM, Wang XW, Jin H, Zhang XP, Fu D, Hou LJ, Lu YC (2014a) Ubiquitin-specific protease 2a stabilizes MDM4 and facilitates the p53-mediated intrinsic apoptotic pathway in glioblastoma. Carcinogenesis 35(7):1500-1509. https ://doi.org/10.1093/carcin/bgu015

Wang L, Chen YJ, Xu K, Wang YY, Shen XZ, Tu RQ (2014b) High expression of UCH37 is significantly associated with poor prognosis in human epithelial ovarian cancer. Tumour Biol 35(11):11427-11433. https://doi.org/10.1007/s1327 7-014-2446-3

Wang B, Ma A, Zhang L, Jin WL, Qian Y, Xu G, Qiu B, Yang Z, Liu Y, Xia Q, Liu Y (2015) POH1 deubiquitylates and stabilizes E2F1 to promote tumour formation. Nat Commun 6:8704. https://doi. org/10.1038/ncomms9704

Wang Q, Ma S, Song N, Li X, Liu L, Yang S, Ding X, Shan L, Zhou X, Su D, Wang Y, Zhang Q, Liu X, Yu N, Zhang K, Shang Y, Yao Z, Shi L (2016) Stabilization of histone demethylase PHF8 by USP7 promotes breast carcinogenesis. J Clin Invest 126(6):2205-2220. https://doi.org/10.1172/JCI85747

Wenzel DM, Lissounov A, Brzovic PS, Klevit RE (2011) UBCH7 reactivity profile reveals parkin and HHARI to be RING/HECT hybrids. Nature 474(7349):105-108. https://doi.org/10.1038/ nature09966

Wicks SJ, Haros K, Maillard M, Song L, Cohen RE, Dijke PT, Chantry A (2005) The deubiquitinating enzyme UCH37 interacts with Smads and regulates TGF-beta signalling. Oncogene 24(54):8080-8084. https://doi.org/10.1038/sj.onc.1208944

Wu N, Liu C, Bai C, Han YP, Cho WC, Li Q (2013) Over-expression of deubiquitinating enzyme USP14 in lung adenocarcinoma promotes proliferation through the accumulation of beta-catenin. Int J Mol Sci 14(6):10749-10760. https://doi.org/10.3390/ijms1 40610749

Xia X, Huang C, Liao Y, Liu Y, He J, Guo Z, Jiang L, Wang X, Liu J, Huang H (2019) Inhibition of USP14 enhances the sensitivity of breast cancer to enzalutamide. J Exp Clin Cancer Res 38(1):220. https://doi.org/10.1186/s13046-019-1227-7

Xu C, Fan CD, Wang X (2015) Regulation of Mdm2 protein stability and the p53 response by NEDD4-1 E3 ligase. Oncogene 34(3):281-289. https://doi.org/10.1038/onc.2013.557

Xu P, Duong DM, Seyfried NT, Cheng D, Xie Y, Robert J, Rush J, Hochstrasser M, Finley D, Peng J (2009) Quantitative proteomics reveals the function of unconventional ubiquitin chains in proteasomal degradation. Cell 137(1):133-145. https://doi. org/10.1016/j.cell.2009.01.041

Yang C, Zang W, Tang Z, Ji Y, Xu R, Yang Y, Luo A, Hu B, Zhang Z, Liu Z, Zheng X (2018) A20/TNFAIP3 regulates the DNA damage response and mediates tumor cell resistance to DNAdamaging therapy. Cancer Res 78(4):1069-1082. https://doi. org/10.1158/0008-5472.CAN-17-2143

Yang H, Lu X, Liu Z, Chen L, Xu Y, Wang Y, Wei G, Chen Y (2015) FBXW7 suppresses epithelial-mesenchymal transition, stemness 
and metastatic potential of cholangiocarcinoma cells. Oncotarget 6(8):6310-6325. https://doi.org/10.18632/oncotarget.3355

Yao WT, Wu JF, Yu GY, Wang R, Wang K, Li LH, Chen P, Jiang YN, Cheng H, Lee HW, Yu J, Qi H, Yu XJ, Wang P, Chu YW, Yang M, Hua ZC, Ying HQ, Hoffman RM, Jeong LS, Jia LJ (2014) Suppression of tumor angiogenesis by targeting the protein neddylation pathway. Cell Death Dis 5:e1059. https://doi. org/10.1038/cddis.2014.21

Yuan T, Yan F, Ying M, Cao J, He Q, Zhu H, Yang B (2018) Inhibition of ubiquitin-specific proteases as a novel anticancer therapeutic strategy. Front Pharmacol 9:1080. https://doi.org/10.3389/fphar .2018.01080

Zeng T, Wang Q, Fu J, Lin Q, Bi J, Ding W, Qiao Y, Zhang S, Zhao W, Lin H, Wang M, Lu B, Deng X, Zhou D, Yin Z, Wang HR (2014) Impeded Nedd4-1-mediated Ras degradation underlies Ras-driven tumorigenesis. Cell Rep 7(3):871-882. https://doi. org/10.1016/j.celrep.2014.03.045

Zhang J, Wan L, Dai X, Sun Y, Wei W (2014) Functional characterization of anaphase promoting complex/cyclosome (APC/C)
E3 ubiquitin ligases in tumorigenesis. Biochim Biophys Acta 1845(2):277-293. https://doi.org/10.1016/j.bbcan.2014.02.001

Zhang X, Linder S, Bazzaro M (2020) Drug development targeting the ubiquitin-proteasome system (UPS) for the treatment of human cancers. Cancers (Basel). https://doi.org/10.3390/cancers 120 40902

Zhu Y, Zhang Y, Sui Z, Zhang Y, Liu M, Tang H (2017) USP14 deubiquitinates vimentin and miR-320a modulates USP14 and vimentin to contribute to malignancy in gastric cancer cells. Oncotarget 8(30):48725-48736. https://doi.org/10.18632/oncot arget.10706

Publisher's Note Springer Nature remains neutral with regard to jurisdictional claims in published maps and institutional affiliations. 